\title{
The Nexus between Financial Development and Economic Growth: Panel Data Evidence from Developing Countries
}

\author{
E. M. Ekanayake ${ }^{1, *}$ and Ranjini Thaver ${ }^{2}$ \\ 1 College of Business and Entrepreneurship, Bethune-Cookman University, 640 Dr. Mary McLeod Bethune \\ Blvd., Daytona Beach, FL 32114, USA \\ 2 Department of Economics, Stetson University, 421 N. Woodland Blvd., DeLand, FL 32723, USA; \\ rthaver@stetson.edu \\ * Correspondence: ekanayakee@cookman.edu; Tel.: +1-(386)-481-2819
}

\section{check for} updates

Citation: Ekanayake, E. M., and Ranjini Thaver. 2021. The Nexus between Financial Development and Economic Growth: Panel Data Evidence from Developing Countries. Journal of Risk and Financial Management 14: 489. https:// doi.org/10.3390/jrfm14100489

Academic Editors: Peter J.

Stauvermann and Ronald Ravinesh Kumar

Received: 2 September 2021

Accepted: 29 September 2021

Published: 14 October 2021

Publisher's Note: MDPI stays neutral with regard to jurisdictional claims in published maps and institutional affiliations.

Copyright: (c) 2021 by the authors. Licensee MDPI, Basel, Switzerland. This article is an open access article distributed under the terms and conditions of the Creative Commons Attribution (CC BY) license (https:// creativecommons.org/licenses/by/ $4.0 /)$.

\begin{abstract}
The objective of this study is to investigate the nexus between financial development (FD) in economic growth (GROWTH) in developing countries. The study uses panel data from 138 developing countries during the period 1980-2018. The relationship between financial development and economic growth is investigated using four explanatory variables that are commonly used to measure the level of financial development and several other control variables, including a dummy variable representing the financial and banking crises. The sample of 138 developing countries is also classified into six geographic regions. We have carried out panel unit-root tests and panel cointegration tests before estimating the specified models using both Panel Least Squares (Panel LS) and Panel Fully Modified Least Squares (FMOLS) methods. In addition, panel Granger causality tests have been conducted to identify the direction of causality between FD and GROWTH for each of the regions. The results of the study provide evidence of a direct relationship between FD and GROWTH in developing countries. Furthermore, there is evidence of bi-directional causality running from FD to GROWTH and from GROWTH to FD in samples of Europe and Central Asia, South Asia, and all countries, but not in East Asia and Pacific, Latin America and the Caribbean, Middle East and North Africa, and Sub-Saharan Africa.
\end{abstract}

Keywords: economic growth; financial development; panel data models; Granger causality tests

\section{Introduction}

The relationship between financial development (FD) and economic growth (EG) has been studied theoretically and empirically since as early as the 1900s. Empirical studies have been conducted on either individual countries such as Bolivia, Egypt, Ghana, and Turkey, or on geographic regions such as North Africa and Sub-Saharan Africa, Asia, the Caribbean, Europe, and Latin America, or by income groups (developing, developed, and emerging countries), among others. Empirical approaches to these studies are equally varied, relying on cross-country or a combination of cross-section and time-series methods spanning Ordinary Least Squares, Generalized Least Squares, Two-Stage Least Squares, the Least Square Dummy Variable Correction method, the Non-Linear Auto Regressive Distributed Lag Model, Fully Modified Ordinary Least Squares, the Panel Vector ErrorCorrection Model, the Generalized Method of Moments, the Generalized Least Squares Method, and Bootstrap panel Granger causality. The financial development variables used in these studies have included-either individually or in combination-domestic credit provided to the private sector (DCPS), domestic credit provided by the banking sector (DCBS), liquid liabilities (ranging from $\mathrm{M}_{1}$ to $\mathrm{M}_{2}$ to $\mathrm{M}_{3}$ ), gross domestic savings (GDS), stock market capitalization (SMC), and the bond market (BM).

Early cross-country studies have concluded that financial development predicts growth, but they were not able to investigate causality and direction in this relationship. In addition, these studies often ignored stationarity or the cointegration of variables 
in the long term. As time-series studies have become more widespread, analysts have refocused their attention on the direction and causality between financial development and growth using panel regression estimation methods. While consensus exists on causality, the direction of that causality seems to differ by region, with well-developed high income countries demonstrating causality from financial development to growth. On the other hand, causality could go either or both ways in developing countries, depending on the use of financial development proxies and the maturity of the financial sector.

Only a few studies have gone on to study the impact of the financial/banking crises on the relationship between financial development and growth, and the focus has been primarily on worldwide samples rather than on developing countries organized by region. The objective of this study is to fill the gap in the literature by investigating the nexus between financial development and economic growth in 138 developing countries from 1980-2018. Moreover, we investigate the impact of the financial/banking crises on economic growth in these countries. Our study investigates this relationship with a few steps. First, we test the presence of panel unit-roots for each of the variables included in our specified models. Second, we test for panel cointegration using three different methods: Pedroni's Heterogeneous Panel Cointegration Test, the Johansen-Fisher Panel Cointegration Test, and the Kao Residual Panel Cointegration Test. These approaches have not been utilized by other studies to our knowledge. Third, we estimate the models using both Panel Least Squares and Panel Fully Modified Least Squares (FMOLS) methods to test for the sensitivity of results to the methodology employed. Finally, causality relationships are tested using the pairwise panel Granger causality test. In addition to this contribution to the literature, we focus on a large sample of 138 developing countries categorized by the World Bank, between 1980-2018, and parse them into six geographical regions: East Asia and Pacific, Europe and Central Asia, Latin America and the Caribbean, Middle East and North Africa, South Asia, and Sub-Saharan Africa. The main reason for parsing countries into six geographic regions is to minimize the heterogeneity commonly found in a large group of developing countries. Such parsing produces a relatively homogeneous sample of countries. This is adequate to identify the nexus between FD and GROWTH. Another reason for this grouping is that it enables us to compare the results among different country groups. The list of countries for each of the six geographic regions is presented in Appendix A Table A4. Other studies have focused on one or more of these regions over a shorter period, but to our knowledge, ours is the only study including all these regions in our sample, while also studying all 138 developing countries and using a longer time period as a pooled sample.

The results of the study provide evidence of a direct relationship between financial development and economic growth in developing countries. Furthermore, there is evidence of bi-directional causality running from financial development to growth and vice versa in samples of Europe and Central Asia, South Asia, and all countries, but not in East Asia and the Pacific, Latin America and the Caribbean, Middle East and North Africa, and Sub-Saharan Africa. Results further reveal that the financial/banking crises significantly impacted growth in the pooled sample of all 138 developing countries. Regionally, the same results hold for East Asia and Pacific, Latin America and the Caribbean, the Middle East, and North Africa. However, in Sub-Saharan Africa, GDS is not significant in both the Panel FMOLS and Panel LS methods. In South Asia, the Panel LS estimation method shows insignificant results regarding the relationship between the financial/banking crises and growth. In Europe and Central Asia, DCPS as a measure of financial development reveals no relationship between the financial/banking crises and growth.

The paper is organized as follows: Section 2 presents a review of the literature, Section 3 presents the methodology and data sources, and Section 4 presents and discusses empirical results, and Section 5 summarizes our conclusions. 


\section{Literature Review}

The relationship between economic growth and financial development has been the focus of a rich variety of studies, including works by famous scholars such as Schumpeter (1911), Kuznets (1955), Lewis (1956), and Rostow (1959), who saw the varying importance of the role of financial development on economic growth but did not view financial development as endogenous to growth. Early empirical studies (Robinson 1952; Patrick 1966) reinforced this claim based on the conventional wisdom that developing countries' financial systems were underdeveloped (Lewis 1956; Adu et al. 2013; Hsueh et al. 2013), contending that technology was the prime determinant in economic growth and that financial development followed as a result of this growth. By the 1980s, however, research actively investigated the economic growth-financial markets nexus. The reasoning behind this approach is that a well-greased financial system offers an increased pooling of resources, reduced risks, reduced transaction and costs and interest rates, increased investments, increased allocation of resources to more profitable organizations, and enhanced entrepreneurship, and therefore greater economic efficiency and growth (Bekaert et al. 2005). Henceforth, most studies, based on varying sample sizes, countries, regions, income groups, time periods, and empirical approaches focused on correlation vs causation and the direction of the FD and growth relationship and causality.

Focusing on developing countries, several studies show a positive relationship between economic growth and financial development, with different causality, or lead-lag effects. Guru and Yadav (2019) examine the relationship between financial development and economic growth using the generalized method of moment system estimation in the BRICS (Brazil, Russia, India, China, and South Africa) countries between 1993 and 2014. Financial development variables utilized in the study include the banking sector and stock market value of shares traded and turnover ratio. Interestingly, the authors include secondary education as a control variable. Overall, their findings reveal that both the banking sector and stock market indicators are complementary in stimulating economic growth among BRICS countries, implying unidirectional causality. Their results contradict Botev et al. (2019), who show no significance of the stock market variable.

Hsueh et al. (2013) apply the bootstrap panel Granger causality method to determine the causality between financial development and economic growth among 10 Asian developing countries between 1980 and 2007. They employ four different FD variables-namely, domestic claims, M1, M2, and M3 - and conclude that the direction of causality between FD and EG depends upon the proxy variables used to define financial development. In the case of China, Indonesia, Korea, Malaysia, Singapore, Thailand, and Taiwan, at least one financial development variable has one-way Granger causality from financial development to growth. Hsueh et al. (2013) state that, in these countries, financial liberalization through conducive monetary policies allowed greater corporate investment, more efficient financial markets, and therefore economic growth. Hsueh et al. (2013), however, do not find any such causality in the Philippines, India, and Japan, and explain that, in the case of Japan at least, the financial crisis of 1997 may have contributed to these results.

Like Hsueh et al. (2013), Adu et al. (2013), employing eight different proxies of financial development to study the effects of financial development on growth in Ghana, conclude that different proxies yield different growth effects. In particular, while private sector credit availability and total domestic credit are conducive for growth, there is no evidence that the ratio of money stock to GDP contributes to economic growth. Similarly, Adusei (2013) applied the FMOLS technique and Pairwise Granger Causality in Botswana between 1981-2010 and found that when DCPS is used as a proxy for financial development, there is a negative relationship, but when $\mathrm{M}_{3}$ is deployed, there is a positive relationship between FD and EG. These authors caution that one of the reasons that other studies (Aghion et al. (2014); Shahbaz et al. (2017)) have found definitive lead-lag relationships may be because they employ only a single financial development indicator.

While many studies support the FD to economic growth causality, they also contend that unsustainable credit liberalization represents a huge cost to growth. For example, 
Ibrahim and Alagidede (2018), relying on panel data for 29 Sub-Saharan African countries between 1980-2014, reveal that while financial development supports economic growth, the extent to which finance helps growth depends crucially on the synchronized growth of the real and financial sectors, and that the financing of risky and unsustainable investments adversely affects economic growth.

Numerous studies have investigated a two-way Granger causality between financial development and economic growth. Several studies, including that of Agbetsiafa (2004) studying the causality nexus of eight Sub-Saharan African countries, find bidirectional causality in Kenya and the Ivory Coast and one-way causality from finance to growth in Ghana, Nigeria, Senegal, South Africa, Togo, and Zambia. Rousseau and Wachtel (2005) and Kemal et al. (2007), using panel data, found a two-way causality relationship in developing countries but no such causality in advanced countries.

Several studies have made a case for financial development contributing to greater economic inequality rather than economic growth. Tiwari et al. (2013), using Indian annual data from 1965 to 2008, used the ARDL bounds testing approach for cointegration to reveal that, in the long term, rural-urban income inequality is worsened by financial development. This was reinforced by Pradhan (2009), who found that EG causes an increase in education.

Destek et al. (2020) extend the financial development and economic inequality nexus in Turkey from 1990 to 2015, based on Rostow's theory of growth and Kuznets' invertedU curve (Kuznets (1955)) hypothesis. Unlike most other studies, they include the bond market as a component of financial development. Utilizing the ARDL bound testing procedure, their results confirm the inverted U-shaped relationship between financial development overall and income inequality, implying a positive relationship between financial development overall and economic growth. They contend that income distribution is adversely affected by financial development in the initial stages of the development of the banking sector, but as economic growth increases, financial risk is mitigated by the banking sector, and this facilitates accessibility to credit by low-income segments of the population. At the same time, they conclude no statistical significance of the bond market with inequality and therefore economic growth. Their study further provides evidence that low-income segments benefit more than high-income segments of the population as a result of financial development and economic growth. The implication of Destek et al. (2020), Tiwari et al. (2013), and Pradhan (2009) to our study is that developing countries, in particular in South Asia and Sub-Saharan Africa, have large rural populations and a large degree of income inequality.

Law et al. (2014), in examining whether the relationship between financial development and income inequality varies with levels of institutional quality, found empirical evidence that there exists an institutional quality threshold effect in the relationship between financial development and income inequality. Financial development tends to reduce income inequality only after a certain threshold level of institutional quality has been achieved. Until then, the effect of financial development on income inequality is nonexistent. This finding suggests that institutional quality affects the link between financial development and income inequality, reflecting the notion that better quality finance results in more equal income distribution.

Ehigiamusoe (2021) examined the nexus between tourism, financial development, and economic growth in 31 African countries using the Dumitrescu-Hurlin Granger noncausality model. The results of the study indicate a bidirectional causality between tourism and economic growth, between financial development and economic growth, and between tourism and financial development, indicating that tourism is a significant predictor of financial development and economic growth in most countries. They conclude that policies that facilitate tourism and financial development will advance economic growth and development.

Yakubu et al. (2021) utilized the ARDL-ECM cointegration model and Granger causality to examine the degree to which Egypt's economic growth was enhanced by financial development, trade, political stability, and government intervention between 1977 and 
2018. They conclude that both financial development and trade openness give evidence of causing growth, and causality goes from these variables to growth. It is of great interest that this study captures political stability as an independent variable but finds that it does not contribute to growth.

Osei and Kim (2020) took the financial development and economic growth relationship a step further by investigating the degree to which enhanced financial development promotes economic growth by making FDI more effective. Employing the dynamic panel threshold model on 62 middle and high-income countries between 1987-2016, their results indicate that while financial development contributes to economic growth through FDI, the effect of financial development on FDI yields diminishing returns and eventually becomes irrelevant. These results are supported by the findings of Lee and Chang (2009) in 37 African countries between 1970-2002 and by Omri et al. (2015) in 12 Middle East and North African countries between 1990-2011.

Song et al. (2021), employing panel cointegration, investigated the consequences of economic growth and corruption on financial development in 142 advanced and developing countries between 2000 and 2016. Their results demonstrate that growth has a positive effect while corruption has an adverse effect on financial development in developing countries, whereas in developed countries, growth positively affects financial development and corruption insignificantly influences financial development.

Hassan et al. (2011) focused their cross-sectional time series panel regression study on the role of financial development and economic growth in low, middle, and high-income countries classified by the World Bank's geographic regions. They also performed Granger causality tests to document the direction of this relationship between financial development and economic growth with the objective of documenting progress in financial liberalization. They conclude that a positive relationship between financial development and economic growth in developing countries exists, but that this is not so in advanced countries. In terms of causality, they find a two-way relationship between financial development and economic growth for most regions and one-way causality from economic growth to financial development for East Asia and Pacific and Sub-Saharan Africa-the two poorest regions in their study. This corroborates the findings of Tiwari et al. (2013) and Kemal et al. (2007), who showed that in developing countries, growth leads finance because of the increasing demand for financial services. These two regions have the lowest GDP per capita in our sample, and not surprisingly, their underdeveloped financial systems do not Granger-cause growth. However, there is a long-term association between finance and growth, as shown in the regression. Simultaneously, trade and government expenditure also contribute to economic growth; thus, they conclude that an efficient financial system is necessary but not sufficient for economic growth in developing countries.

Using non-linear estimation techniques, Botev et al. (2019) examined the relationship between financial development and economic growth in 107 developing, emerging, and developed market economies. They hypothesized that after the financial crisis of 2008, financial development would have a negative effect on growth. They defined several proxies for financial development to include, as a share of GDP, credit to the domestic economy, credit to the private domestic economy, and stock market capitalization, as well as the number of branches per capita and a financial liberalization index. The results of their study reveal a positive relationship between economic growth and financial development. In particular, banking and market finances reinforce each other's positive effect on economic performance, with banking finance having a greater impact when stock markets are highly developed, as in the case of advanced countries, than when they are weak, as in the case of developing and emerging market economies. However, they do not find a negative relationship between financial development and economic growth after the financial crisis.

This paper adopts the methods presented in Botev et al. (2019) and Hassan et al. (2011), integrating the assumption of coefficient heterogeneity and cross-sectional dependency concurrently while examining the test of panel data causality. This approach is carried out using Pedroni's Heterogeneous Panel Cointegration Test, the Johansen-Fisher Panel 
Cointegration Test, and the Kao Residual Panel Cointegration Test. Using these methods for developing countries is appropriate because of the different degrees of economic development among the different regions.

\section{Methodology and Data}

\subsection{Model Specification}

The objective of this study is to investigate the nexus between financial development and economic growth. Drawing on the existing empirical literature (see, for example, Botev et al. (2019) and Hassan et al. (2011)), the starting point is a growth regression including the following explanatory variables: (a) the growth rate of physical capital (investment as a percentage of GDP; GRK) and (b) the growth rate of the labor force (GRL). This specification of the growth regression can be extended by adding the following control variables: (a) trade openness (measured as (exports+imports)/GDP; OPEN), (b) government expenditure as a share of GDP (GOV), and (c) the inflation rate measured using the consumer price index (INF). Adding a variable representing financial development (FD) yields the following empirical specification:

$$
G R O W T H_{i, t}=f\left(G R K_{i, t}, G R L_{i, t}, O P E N_{i, t}, G O V_{i, t}, I N F_{i, t}, F D_{i, t}\right)
$$

where GROWTH is the growth rate of real GDP per capita; $i$ and $t$ subscripts are defined as $i=1,2, \ldots, 138$ and $t=1,2, \ldots \ldots, 39 ; G R K_{i, t}$ is the growth rate of capital stock; $G R L_{i, t}$ is the growth rate of labor force; OPEN $N_{i, t}$ is the exports plus imports as a share of GDP; $G O V_{i, t}$ is the government expenditure as a share of GDP; $I N F_{i, t}$ is the inflation rate measured using the consumer price index (CPI); and $F D_{i, t}$ is the variable representing financial development.

In this study, we use four proxy variables to measure the level of financial development. These are (a) domestic credit to the private sector as a share of GDP (DCPS); (b) domestic credit to the private sector by banks as a share of GDP (DCBS); (c) broad money or liquid liabilities as a share of GDP $(L L)$; and (d) gross domestic savings as a share of GDP (DCPS). The World Bank defines these four variables as follows: domestic credit to the private sector $(D C P S)$ refers to financial resources provided to the private sector by financial corporations, such as loans, purchases of nonequity securities, and trade credits and other accounts receivable, that establish a claim for repayment; domestic credit to the private sector by banks (DCBS) refers to financial resources provided to the private sector by other depository corporations (deposit taking corporations except central banks), such as loans, purchases of nonequity securities, and trade credits and other accounts receivable, that establish a claim for repayment; broad money or liquid liabilities $(L L)$ is the sum of currency outside banks, demand deposits other than those of the central government, the time, savings, and foreign currency deposits of resident sectors other than the central government, bank and traveler's checks, and other securities such as certificates of deposit and commercial paper; and gross domestic savings (GDS) are calculated as GDP minus the final consumption expenditure (total consumption). Since these four financial development variables are highly correlated, they are separated into four different models. In addition, we have also included a dummy variable to represent a banking or economic crisis $(B C D)$. Assuming that the model specified in Equation (1) is linear, we can write the following empirical specification of our growth model:

$\mathrm{GROWTH}_{i, t}=\beta_{0}+\beta_{1} G R K_{i, t}+\beta_{2} G R L_{i, t}+\beta_{3} O P E N_{i, t}+\beta_{4} G O V_{i, t}+\beta_{5} I N F_{i, t}+\beta_{6} B C D_{i, t}+\beta_{7} F D_{i, t}+\varepsilon_{i, t}$

where $i$ and $t$ subscripts are defined as $i=1,2, \ldots, 138$ and $t=1,2, \ldots \ldots, 39 ; B C D_{i, t}$ is a dummy variable representing a banking or economic crisis; and $\varepsilon_{i, t}$ is the error term. Other variables are defined above. A priori, the signs of variables $G R K_{i, t}$ and $G R L_{i, t}$ are expected to be positive. Since economies that are more open tend to grow faster than relatively closed economies, the expected sign of the $O P E N_{i, t}$ variable is also positive. The expected sign of the $G O V_{i, t}$ variable can be either positive or negative. The expected sign of the 
$I N F_{i, t}$ variable is negative. Since any banking or economic crisis tends to reduce economic growth, the expected sign of the $B C D_{i, t}$ variable is negative. The expected sign of the $F D_{i, t}$ variable can be either positive or negative depending on whether financial development enhances or deters economic growth.

\subsection{Definition of Variables and Data Sources}

The dependent variable, GROWTH, is the growth rate of real GDP per capita. The growth rate of physical capital (GRK) is measured by a proxy variable: namely, gross fixed capital formation as a percent of GDP. The growth rate of labor $(G R L)$ is measured by a proxy variable: namely, the growth rate of population. The trade openness (OPEN) variable is measured as (exports + imports)/GDP. The government expenditure (GOV) variable is calculated as government expenditure as a share of GDP. The inflation (INF) variable is measured as the annual percentage change in the consumer price index. The data on GROWTH, GRK, GRL, OPEN, GOV , and INF variables were collected from the World Bank, World Development Indicators 2021 database. Data on four financial development variables-namely, domestic credit to private sector as a share of GDP (DCPS); domestic credit to private sector by banks as a share of GDP (DCBS); broad money or liquid liabilities as a share of GDP $(L L)$; and gross domestic savings as a share of GDP (GDS) - were also collected from the World Bank, World Development Indicators 2021 database. In addition, we have included a dummy variable to represent a banking or economic crisis $(B C D)$. Information on the banking crisis dummy was collected from the World Bank, Global Financial Development Database (GFDD) 2019.

\section{Empirical Results}

\subsection{Summary Statistics}

In this section, we discuss the study's findings and empirical results. Table 1 presents the summary statistics by region. The selected sample of 138 developing countries was grouped by six geographic regions. Based on the median per capita GDP, Latin America and the Caribbean have the highest GDP per capita, followed by Middle East and North Africa, Europe and Central Asia, and East Asia and the Pacific. South Asia and Sub-Saharan Africa have the lowest median GDP per capita. These results corroborate those of Hassan et al. (2011), but this study shows greater maximum and lower minimum values because it includes data during the financial crisis of 2007-2009. Europe and Central Asia, East Asia and the Pacific, and South Asia post the highest average growth rates, while the Middle East and North Africa and Sub-Saharan Africa have the lowest growth rates of all six regions. Latin America and the Caribbean and Sub-Saharan Africa have growth rates below the median value of all countries. The sample in this study, furthermore, shows higher growth rate gaps among all countries than Hassan et al. (2011), which is likely to be because of the impact of the financial crisis on economic growth. In terms of the four financial development variables, the Middle East and North Africa have the highest mean values, followed by Latin America and the Caribbean and East Asia and the Pacific. Notably, Sub-Saharan Africa posts the lowest median values in all four indicators, which are lower than Hassan et al. (2011), reflecting their relatively undeveloped financial sector overall. 
Table 1. Summary statistics by region (1980-2018).

\begin{tabular}{|c|c|c|c|c|c|c|c|c|c|c|c|}
\hline & \multicolumn{2}{|c|}{ Economic Growth } & \multicolumn{4}{|c|}{ Financial Development } & \multicolumn{5}{|c|}{ Real Sector } \\
\hline & $\begin{array}{l}\text { GDP per Capita } \\
\text { (US \$) }\end{array}$ & $\begin{array}{l}\text { Growth } \\
(\%)\end{array}$ & $\begin{array}{c}\text { GCPS } \\
(\%)\end{array}$ & $\begin{array}{c}\text { DCBS } \\
(\%)\end{array}$ & $\begin{array}{l}\mathrm{LL} \\
(\%)\end{array}$ & $\begin{array}{c}\text { GDS } \\
(\%)\end{array}$ & $\begin{array}{c}\text { GRK } \\
(\%)\end{array}$ & $\begin{array}{l}\text { GRL } \\
(\%)\end{array}$ & $\begin{array}{c}\text { GOV } \\
(\%)\end{array}$ & $\begin{array}{l}\text { INF } \\
(\%)\end{array}$ & $\begin{array}{c}\text { OPEN } \\
(\%)\end{array}$ \\
\hline \multicolumn{12}{|c|}{ Full Sample ( $\mathrm{N}=138)$} \\
\hline Mean & 5539.6 & 1.9 & 33.7 & 29.5 & 44.4 & 22.0 & 22.0 & 1.9 & 19.7 & 34.0 & 75.8 \\
\hline Median & 2758.0 & 2.1 & 26.1 & 23.3 & 36.5 & 20.9 & 20.9 & 2.0 & 16.6 & 6.2 & 69.4 \\
\hline Max & $116,233.0$ & 43.4 & 242.0 & 166.5 & 260.1 & 89.4 & 89.4 & 17.5 & 83.6 & $23,773.1$ & 375.4 \\
\hline Min & 164.0 & -47.5 & 0.0 & 0.0 & 0.0 & -142.0 & -2.4 & -6.8 & 0.0 & -20.6 & 0.0 \\
\hline \multicolumn{12}{|c|}{ East Asia and Pacific $(\mathrm{N}=18)$} \\
\hline Mean & 3430.1 & 2.8 & 44.1 & 41.5 & 55.7 & 27.0 & 25.5 & 1.6 & 19.9 & 10.7 & 88.0 \\
\hline Median & 2010.2 & 3.4 & 31.6 & 29.9 & 42.2 & 32.1 & 25.5 & 1.6 & 16.3 & 5.2 & 87.9 \\
\hline Max & $37,399.7$ & 15.5 & 158.5 & 166.5 & 207.7 & 68.5 & 69.3 & 3.5 & 83.6 & 411.0 & 220.4 \\
\hline Min & 187.5 & -37.0 & 0.9 & 0.0 & 0.0 & -26.6 & 4.6 & -0.9 & 0.0 & -9.2 & 0.2 \\
\hline \multicolumn{12}{|c|}{ Europe \& Central Asia $(\mathrm{N}=20)$} \\
\hline Mean & 3430.1 & 3.5 & 36.6 & 29.5 & 38.8 & 19.2 & 22.8 & 0.0 & 27.6 & 60.1 & 86.0 \\
\hline Median & 2010.2 & 4.2 & 32.8 & 26.3 & 20.6 & 20.6 & 22.1 & -0.2 & 28.2 & 7.4 & 83.0 \\
\hline Max & $16,793.4$ & 35.4 & 90.7 & 82.8 & 85.8 & 58.1 & 57.7 & 2.5 & 53.5 & 4734.9 & 175.4 \\
\hline Min & 381.4 & -40.7 & 3.5 & 1.2 & 6.7 & -17.5 & 4.0 & -3.8 & 0.0 & -10.6 & 17.1 \\
\hline \multicolumn{12}{|c|}{ Latin America \& Caribbean $(\mathrm{N}=33)$} \\
\hline Mean & 7642.3 & 1.6 & 41.9 & 36.0 & 49.3 & 18.5 & 20.1 & 1.3 & 18.7 & 70.9 & 75.0 \\
\hline Median & 5823.7 & 1.7 & 36.5 & 32.4 & 45.2 & 19.7 & 19.8 & 1.4 & 15.9 & 5.6 & 66.1 \\
\hline Max & $32,236.5$ & 20.1 & 242.0 & 133.1 & 150.7 & 46.1 & 51.8 & 6.0 & 65.2 & $13,611.6$ & 275.0 \\
\hline Min & 1029.2 & -15.2 & 0.0 & 0.0 & 0.0 & -13.2 & 5.8 & -1.8 & 0.0 & -11.4 & 11.5 \\
\hline \multicolumn{12}{|c|}{ Middle East \& North Africa $(\mathrm{N}=17)$} \\
\hline Mean & $15,436.6$ & 0.8 & 46.9 & 41.3 & 73.4 & 29.1 & 24.8 & 3.2 & 21.9 & 6.6 & 85.8 \\
\hline Median & 5501.5 & 1.0 & 48.7 & 41.4 & 61.7 & 27.2 & 24.4 & 2.6 & 22.4 & 3.7 & 81.8 \\
\hline Max & $116,232.8$ & 121.8 & 106.3 & 105.2 & 260.1 & 75.5 & 44.1 & 17.5 & 46.5 & 97.4 & 251.1 \\
\hline Min & 1013.2 & -62.4 & 3.0 & 0.0 & 0.0 & -17.9 & 8.9 & -0.1 & 0.0 & -20.6 & 0.0 \\
\hline \multicolumn{12}{|c|}{ South Asia $(\mathrm{N}=7)$} \\
\hline Mean & 1731.7 & 3.7 & 26.6 & 26.4 & 44.9 & 19.0 & 26.2 & 1.9 & 16.7 & 7.7 & 64.4 \\
\hline Median & 916.0 & 3.7 & 24.1 & 24.1 & 42.6 & 17.9 & 23.6 & 2.0 & 15.6 & 7.5 & 47.3 \\
\hline Max & 8157.4 & 24.6 & 86.6 & 86.5 & 109.0 & 44.6 & 69.7 & 4.6 & 31.2 & 26.1 & 375.4 \\
\hline Min & 280.9 & -15.4 & 2.5 & 2.5 & 14.1 & 2.1 & 12.5 & -0.4 & 7.6 & -18.1 & 12.2 \\
\hline \multicolumn{12}{|c|}{ Sub-Saharan Africa $(\mathrm{N}=43)$} \\
\hline Mean & 2004.8 & 1.3 & 18.6 & 15.8 & 27.7 & 15.6 & 20.1 & 2.6 & 17.7 & 39.6 & 66.9 \\
\hline Median & 841.5 & 1.4 & 12.9 & 11.9 & 21.3 & 15.3 & 18.8 & 2.7 & 16.0 & 6.9 & 57.6 \\
\hline Max & $20,533.0$ & 140.4 & 160.1 & 106.3 & 164.1 & 88.4 & 89.4 & 8.1 & 52.2 & $23,773.1$ & 311.4 \\
\hline Min & 164.3 & -47.5 & 0.0 & 0.0 & 0.0 & -142.0 & -2.4 & -6.8 & 0.0 & -18.2 & 6.3 \\
\hline
\end{tabular}

Note: This table summarizes the country-year statistics for six geographic regions classified according to the World Bank. GDP per capita is the real GDP per capita measured in 2010 dollars; GROWTH is the growth rate of real GDP per capita; DCPS is the domestic credit provided to the private sector as a share of GDP; DCBS is the domestic credit provided by banking sector as a share of GDP; LL is the liquid liabilities as a share of GDP; GDS is the gross domestic savings as a share of GDP; GRK is the gross fixed capital formation as a share of GDP; GRL is the growth rate of the labor force; GOV is the government expenditure as a share of GDP; and OPEN is the exports plus imports as a share of GDP. Detailed definitions of variables are presented in definition of variables and data sources section.

\subsection{Panel Unit-Root Tests and Panel Co-Integration Tests}

The starting point of our econometric analysis was to check whether the variables included in Equations (1)-(3) contain panel unit-roots. Panel unit-root tests by Levin et al. (2002), Breitung (2000), Im et al. (2003), Maddala and Wu (1999), Choi (2001), and Hadri (2000) were used to test whether the variables included in Equations (1)-(3) contain panel unit-roots before carrying out panel cointegration tests. All the variables were found to be integrated of order one. To shorten the length of the paper, we have not reported the results of the panel unit-root tests. We then tested whether the variables included in Equations (1)-(3) are co-integrated utilizing three different methods: namely, the JohansenFisher Panel Cointegration Test, Pedroni's Heterogeneous Panel Cointegration Test, and Kao Residual Panel Cointegration Test. The results of the Johansen-Fisher Panel Cointegration Test are reported in Table 2, while the results of Pedroni's Heterogeneous Panel Cointegration Test and Kao Residual Panel Cointegration Test are reported in Appendix A, Tables A1 and A2. 
Table 2. Johansen-Fisher Panel Cointegration Tests.

\begin{tabular}{|c|c|c|c|c|c|c|c|c|c|c|c|c|c|c|}
\hline \multicolumn{15}{|c|}{ Panel A: Series: GROWTH, GRK, GRL, GOV, OPEN, INF, DCPS } \\
\hline \multicolumn{8}{|c|}{ Fisher Statistic (from Trace Test) } & \multicolumn{7}{|c|}{ Fisher Statistic (from Max-Eigen Test) } \\
\hline Region & $\mathbf{r}=\mathbf{0}$ & $\mathrm{r} \leq 1$ & $\mathbf{r} \leq 2$ & $\mathbf{r} \leq 3$ & $\mathrm{r} \leq 4$ & $\mathbf{r} \leq 5$ & $r \leq 6$ & $\mathbf{r}=\mathbf{0}$ & $\mathrm{r} \leq 1$ & $\mathbf{r} \leq 2$ & $\mathbf{r} \leq 3$ & $\mathrm{r} \leq 4$ & $\mathbf{r} \leq \mathbf{5}$ & $\mathbf{r} \leq 6$ \\
\hline EAP & $320.1^{*}$ & $178.9 *$ & $94.5^{*}$ & $95.8 *$ & $71.5 *$ & 37.2 & 31.0 & 246.1 * & $97.3 *$ & $64.1 *$ & $66.5^{*}$ & 52.0 & 24.2 & 31.0 \\
\hline ECA & $627.0 *$ & $533.9 *$ & $365.9 *$ & $160.8^{*}$ & $98.6^{*}$ & $64.4 *$ & 49.1 & $5 *$ & $287.6^{*}$ & $194.4^{*}$ & $155.7^{*}$ & $88.1^{*}$ & 55.5 & 49.1 \\
\hline LAC & $697.7 *$ & $370.0 *$ & $183.4^{*}$ & $88.8 *$ & 56.4 & 43.0 & 72.1 & $489.3 *$ & $228.8 *$ & $125.4^{*}$ & $56.4 *$ & 41.1 & 31.5 & 72.1 \\
\hline MENA & $262.6^{*}$ & $210.7^{*}$ & $126.7^{*}$ & $74.1^{*}$ & $43.7 *$ & 26.7 & 19.1 & $141.3 *$ & $107.7^{*}$ & $69.8 *$ & $43.9 *$ & 30.7 & 23.5 & 19.1 \\
\hline SOA & $176.6^{*}$ & $90.9 *$ & 46.4 * & 25.6 & 14.9 & 11.3 & 8.2 & 145.1 * & $53.8 *$ & $28.3^{*}$ & 17.1 & 10.5 & 9.9 & 8.2 \\
\hline SSA & $804.5 *$ & $382.2 *$ & $195.1^{*}$ & $104.0 *$ & 69.4 & 59.3 & 36.5 & $599.1 *$ & $231.9^{*}$ & $127.2 *$ & 66.9 & 47.8 & 45.9 & 36.5 \\
\hline ALL & 727.0 * & $380.0 *$ & $268.4^{*}$ & 118.8 * & 86.4 * & 53.0 & 32.1 & $789.3 *$ & 328.8 * & 225.4 * & $156.4^{*}$ & $98.1 *$ & 52.5 & 32.1 \\
\hline
\end{tabular}

Panel B: Series: GROWTH, GRK, GRL, GOV, OPEN, INF, DCBS

\begin{tabular}{|c|c|c|c|c|c|c|c|c|c|c|c|c|c|c|}
\hline \multirow[b]{2}{*}{ Region } & \multicolumn{7}{|c|}{ Fisher Statistic (from Trace Test) } & \multicolumn{7}{|c|}{ Fisher Statistic (from Max-Eigen Test) } \\
\hline & $\mathbf{r}=\mathbf{0}$ & $\mathrm{r} \leq 1$ & $\mathrm{r} \leq 2$ & $\mathrm{r} \leq 3$ & $\mathrm{r} \leq 4$ & $\mathrm{r} \leq 5$ & $r \leq 6$ & $\mathbf{r}=\mathbf{0}$ & $\mathrm{r} \leq 1$ & $\mathbf{r} \leq 2$ & $\mathrm{r} \leq 3$ & $\mathrm{r} \leq 4$ & $\mathrm{r} \leq 5$ & $r \leq 6$ \\
\hline EAP & $310.9 *$ & 231.1 * & $143.5^{*}$ & $93.6^{*}$ & $69.0 *$ & 35.2 & 23.9 & $265.9 *$ & $124.0 *$ & $103.4^{*}$ & $66.9 *$ & $51.3^{*}$ & 26.9 & 23.9 \\
\hline ECA & $674.2 *$ & 514.8 * & 396.1 * & $193.9 *$ & $89.4^{*}$ & 58.6 & 42.1 & $671.1 *$ & $344.5 *$ & $173.7^{*}$ & $96.4^{*}$ & $63.9 *$ & 51.5 & 42.1 \\
\hline LAC & $600.9 *$ & 317.5 * & $153.6^{*}$ & $81.7^{*}$ & 51.7 & 46.9 & 33.1 & 340.1 * & $201.2 *$ & $100.4^{*}$ & $55.3^{*}$ & 42.3 & 38.7 & 33.1 \\
\hline MENA & $270.2^{*}$ & 207.6 * & $118.6 *$ & $69.3^{*}$ & $41.3^{*}$ & 25.9 & 18.2 & $154.4^{*}$ & $115.9^{*}$ & $66.9 *$ & $41.1^{*}$ & 29.1 & 20.4 & 18.2 \\
\hline SOA & $181.7^{*}$ & $99.8 *$ & $47.3^{*}$ & $27.1^{*}$ & 14.3 & 9.8 & 8.2 & $208.9 *$ & $62.9^{*}$ & $27.2 *$ & 19.6 & 11.1 & 9.4 & 8.2 \\
\hline SSA & $958.5 *$ & $493.1 *$ & $245.9 *$ & $138.3 *$ & 89.4 & 71.1 & 56.5 & $874.1^{*}$ & 299.6 * & $145.2 *$ & $92.5^{*}$ & 86.3 & 65.9 & 56.5 \\
\hline ALL & $757.0^{*}$ & $390.0 *$ & $284.4^{*}$ & 136.8 * & $96.4 *$ & 43.0 & 33.5 & $765.3 *$ & $336.8 *$ & 125.4 * & $96.7 *$ & $78.1 *$ & 42.5 & 33.5 \\
\hline
\end{tabular}

Panel C: Series: GROWTH, GRK, GRL, GOV, OPEN, INF, LL

\begin{tabular}{|c|c|c|c|c|c|c|c|c|c|c|c|c|c|c|}
\hline \multirow[b]{2}{*}{ Region } & \multicolumn{7}{|c|}{ Fisher Statistic (from Trace Test) } & \multicolumn{7}{|c|}{ Fisher Statistic (from Max-Eigen Test) } \\
\hline & $\mathbf{r}=\mathbf{0}$ & $\mathbf{r} \leq 1$ & $\mathbf{r} \leq 2$ & $\mathbf{r} \leq 3$ & $\mathbf{r} \leq 4$ & $\mathbf{r} \leq 5$ & $\mathbf{r} \leq 6$ & $r=0$ & $\mathbf{r} \leq \mathbf{1}$ & $\mathbf{r} \leq 2$ & $\mathbf{r} \leq 3$ & $r \leq 4$ & $\mathbf{r} \leq 5$ & $r \leq 6$ \\
\hline EAP & 304.1 * & 161.6 * & $108.9 *$ & $95.8 *$ & $64.4^{*}$ & 39.5 & 33.1 & $200.2 *$ & 90.4 * & $55.5 *$ & $74.1 *$ & 48.6 * & 27.9 & 23.1 \\
\hline ECA & 624.4 * & $449.7 *$ & $222.7 *$ & $98.8 *$ & $66.6 *$ & 53.0 & 42.5 & $667.6 *$ & $168.6 *$ & 152.6 * & 86.4 * & $64.1 *$ & 54.5 & 42.5 \\
\hline LAC & 577.6 * & 290.9 * & 158.8 * & $89.8 *$ & 61.0 & 45.0 & 36.3 & 347.0 * & 160.1 * & $91.8 *$ & 53.4 * & 44.7 & 40.9 & 36.3 \\
\hline MENA & 343.4 * & 205.8 * & 119.7 * & $68.7 *$ & 34.6 & 24.9 & 16.1 & 300.2 * & 111.7 * & $68.7 *$ & 48.7 & 33.6 & 22.9 & 16.1 \\
\hline SOA & 167.2 * & $78.8^{*}$ & $41.6 *$ & $28.9 *$ & 12.4 & 9.6 & 7.4 & 123.6 * & $45.5 *$ & $26.4 *$ & 16.6 & 8.7 & 8.1 & 7.4 \\
\hline SSA & 874.6 * & 471.6 * & $240.9 *$ & 137.8 * & 86.4 & 52.3 & 36.4 & $701.1 *$ & 289.0 * & 138.8 * & 82.5 & 71.4 & 48.9 & 36.4 \\
\hline ALL & 731.1 * & 348.0 * & $234.1 *$ & $99.8 *$ & $76.4^{*}$ & 39.1 & 28.1 & $719.2 *$ & 311.7 * & 202.4 * & 96.4 * & $68.1 *$ & 40.5 & 28.1 \\
\hline
\end{tabular}

Note: This table shows the results of the Johansen-Fisher Panel Cointegration Test. $r$ denotes the number of cointegrating vectors. The optimal lag length for the VARs were selected by minimizing the Schwarz criterion. The sign * indicates statistical significance of the Fisher statistic at the 1\% level. EAP = East Asia and Pacific; ECA = Europe and Central Asia; LAC = Latin America and the Caribbean; MENA = Middle East and North Africa; SOA = South Asia; SSA = Sub-Saharan Africa; and ALL = all countries .

The Pedroni's Heterogeneous Panel Cointegration Test results, presented in Appendix A Table A1, show evidence of cointegration among the seven variables for each of the six regions as well as for the all-countries sample. Since each of the financial development indicators is introduced individually, the results are presented in Panels A, B, and C in Appendix A Table A1. Of the seven tests, the panel v-statistic is a one-sided test where large positive values reject the null hypothesis of no cointegration, whereas large negative values for the remaining six test statistics reject the null hypothesis of no cointegration. The number of lag length was selected automatically based on the SIC with a maximum lag of 8. Regardless of which financial development indicator was used, of the seven test statistics, only one of the panel $v$-statistic was not statistically significant. Thus, we decided to verify the results using additional tests of panel cointegration. Table 2 shows the results of the Johansen-Fisher Panel Cointegration Test. In the table, $r$ denotes the number of cointegrating vectors. The optimal lag length for the VARs were selected by minimizing the Schwarz criterion. Both the trace-test and the maximum-eigenvalues test show evidence for the presence of at least two cointegrating vectors for all six geographic regions as well as for the all-countries sample. Unlike Pedroni's Heterogeneous Panel Cointegration Test, the Johansen-Fisher Panel Cointegration Test shows clear evidence of cointegration among all seven variables for all geographic regions, regardless of which measure of financial development is used. Similarly, the results of the Kao Residual Panel Cointegration Test, presented in Appendix A Table A2 show that the test statistic is statistically significant at the $1 \%$ level, rejecting the null hypothesis of no cointegration for all geographic regions as 
well as for all countries. Thus, the Kao Residual Panel Cointegration Test also shows clear evidence of cointegration among seven variables for all geographic regions, regardless of which measure of financial development is used.

\subsection{Analysis of Panel Regressions}

Having tested the presence of cointegration or a long-term relationship among the seven variables, the next step involved the estimation of the specified panel regression models. For this purpose, we used two estimation methods: namely, the Panel Least Squares and the Panel Fully Modified Least Squares (FMOLS) methods. The results of the panel regression models for the all-countries sample are presented in Table 3. Appendix A Table A3 shows similar results for each of the six geographic regions. Since our selected indicators of financial development are highly correlated, each of the indicators is introduced separately to Models 1-4 (Panel LS) and Models 5-8 (Panel FMOLS) in these tables.

Table 3. Economic growth regressions (all-countries sample).

\begin{tabular}{|c|c|c|c|c|c|c|c|c|}
\hline \multirow{2}{*}{ Variable } & \multicolumn{4}{|c|}{ Panel Least Squares } & \multicolumn{4}{|c|}{ Panel Fully Modified Least Squares (FMOLS) } \\
\hline & Model 1 & Model 2 & Model 3 & Model 4 & Model 5 & Model 6 & Model 7 & Model 8 \\
\hline Constant & $\begin{array}{l}7.0672^{* * *} \\
(0.0001)\end{array}$ & $\begin{array}{l}7.1105^{* * *} \\
(0.0001)\end{array}$ & $\begin{array}{l}7.0324^{* * *} \\
(0.0001)\end{array}$ & $\begin{array}{l}7.1076^{* * *} \\
(0.0001)\end{array}$ & & & & \\
\hline GRK & $\begin{array}{c}0.0120^{* * *} \\
(0.0004)\end{array}$ & $\begin{array}{c}0.0108^{* * *} \\
(0.0003)\end{array}$ & $\begin{array}{c}0.0108^{* * *} \\
(0.0004)\end{array}$ & $\begin{array}{c}0.0112^{* * * *} \\
(0.0001)\end{array}$ & $\begin{array}{c}0.0214^{* * *} \\
(0.0003)\end{array}$ & $\begin{array}{c}0.0135^{* * *} \\
(0.0002)\end{array}$ & $\begin{array}{c}0.0137^{* * *} \\
(0.0001)\end{array}$ & $\begin{array}{c}0.0155^{* * *} \\
(0.0004)\end{array}$ \\
\hline$G R L$ & $\begin{array}{l}0.0244^{* * *} \\
(0.0049)\end{array}$ & $\begin{array}{l}0.0127 * \\
(0.0764)\end{array}$ & $\begin{array}{l}0.0122 * \\
(0.0692)\end{array}$ & $\begin{array}{l}0.0356^{* * *} \\
(0.0004)\end{array}$ & $\begin{array}{l}0.0957^{* * *} \\
(0.0010)\end{array}$ & $\begin{array}{c}0.0574 * * * \\
(0.0049)\end{array}$ & $\begin{array}{c}0.0366 \\
(0.1995)\end{array}$ & $\begin{array}{c}0.1371^{* * *} \\
(0.0001)\end{array}$ \\
\hline GOV & $\begin{array}{l}0.0109 * * * \\
(0.0001)\end{array}$ & $\begin{array}{l}0.0074^{* * *} \\
(0.0001)\end{array}$ & $\begin{array}{l}0.0078^{* * *} \\
(0.0005)\end{array}$ & $\begin{array}{l}0.0126^{* * *} \\
(0.0001)\end{array}$ & $\begin{array}{c}0.0219 * * * \\
(0.0001)\end{array}$ & $\begin{array}{c}0.0109 * * * \\
(0.0001)\end{array}$ & $\begin{array}{l}0.0116^{* * *} \\
(0.0034)\end{array}$ & $\begin{array}{c}0.0215^{* * *} \\
(0.0001)\end{array}$ \\
\hline OPEN & $\begin{array}{l}0.0022 * * * \\
(0.0001)\end{array}$ & $\begin{array}{l}0.0014 * * * \\
(0.0001)\end{array}$ & $\begin{array}{l}0.0017^{* * *} \\
(0.0001)\end{array}$ & $\begin{array}{c}0.0029 * * * \\
(0.0001)\end{array}$ & $\begin{array}{l}0.0040 * * * \\
(0.0001)\end{array}$ & $\begin{array}{l}0.0022 * * * \\
(0.0001)\end{array}$ & $\begin{array}{c}0.0013 \\
(0.7597)\end{array}$ & $\begin{array}{l}0.0041^{* * *} \\
(0.0001)\end{array}$ \\
\hline INF & $\begin{array}{c}-0.0001 \\
(0.0122)\end{array}$ & $\begin{array}{c}-0.0001^{* *} \\
(0.0085)\end{array}$ & $\begin{array}{c}-0.0001^{* *} \\
(0.0167)\end{array}$ & $\begin{array}{c}-0.0001 * * * \\
(0.0016)\end{array}$ & $\begin{array}{l}-0.0001 \\
(0.8480)\end{array}$ & $\begin{array}{c}-0.0001 \\
(0.0122)\end{array}$ & $\begin{array}{l}-0.0001 \\
(0.2199)\end{array}$ & $\begin{array}{l}-0.0001 \\
(0.6330)\end{array}$ \\
\hline$B C D$ & $\begin{array}{c}-0.1298^{* * *} \\
(0.0001)\end{array}$ & $\begin{array}{c}-0.1170 * * * \\
(0.0001)\end{array}$ & $\begin{array}{c}-0.0840^{* * *} \\
(0.0001)\end{array}$ & $\begin{array}{c}-0.1313^{* * *} \\
(0.0001)\end{array}$ & $\begin{array}{c}-0.1556^{* * *} \\
(0.0049)\end{array}$ & $\begin{array}{c}-0.1298^{* * *} \\
(0.0001)\end{array}$ & $\begin{array}{c}-0.1080 * * \\
(0.0370)\end{array}$ & $\begin{aligned}- & 0.1561^{* * *} \\
& (0.0042)\end{aligned}$ \\
\hline$D C P S$ & $\begin{array}{c}0.0063^{* * *} \\
(0.0001)\end{array}$ & & & & $\begin{array}{c}0.0046^{* * *} \\
(0.0001)\end{array}$ & & & \\
\hline$D C B S$ & & $\begin{array}{l}0.0099 * * * \\
(0.0001)\end{array}$ & & & & $\begin{array}{l}0.0136^{* * *} \\
(0.0001)\end{array}$ & & \\
\hline$L L$ & & & $\begin{array}{c}0.0077^{* * *} \\
(0.0001)\end{array}$ & & & & $\begin{array}{l}0.0128^{* * *} \\
(0.0001)\end{array}$ & \\
\hline GDS & & & & $\begin{array}{l}0.0059^{* * *} \\
(0.0001)\end{array}$ & & & & $\begin{array}{l}0.0157^{* * * *} \\
(0.0001)\end{array}$ \\
\hline Country FE & Yes & Yes & Yes & Yes & Yes & Yes & Yes & Yes \\
\hline Time FE & No & No & No & No & No & No & No & No \\
\hline Adj. $R^{2}$ & 0.9491 & 0.9547 & 0.9538 & 0.9433 & 0.9173 & 0.9556 & 0.9527 & 0.9190 \\
\hline Obs. & 4731 & 4696 & 4706 & 4860 & 2173 & 2181 & 2193 & 2348 \\
\hline No.countries & 138 & 138 & 138 & 138 & 138 & 138 & 138 & 138 \\
\hline
\end{tabular}

Note: This table shows the regression results for economic growth determinants for all-countries sample. The heteroskedastic-robust adjusted standard errors are in parentheses. The signs $* * * * *$, and * indicate statistical significance of the F-statistic at $1 \%, 5 \%$, and $10 \%$ levels, respectively. Each equation is estimated using Panel Least Squares and Panel Fully Modified Least Squares estimation methods. GROWTH is the growth rate of real GDP per capita; DCPS is the domestic credit provided to the private sector as a share of GDP; DCBS is the domestic credit provided by banking sector as a share of GDP; LL is the liquid liabilities as a share of GDP; GDS is the gross domestic savings as a share of GDP; GRK is the gross fixed capital formation as a share of GDP; GRL is the growth rate of the labor force; OPEN is the exports plus imports as a share of GDP; GOV is the government expenditure as a share of GDP; INF is the inflation rate measured using the consumer price index (CPI); and BCD is a dummy variable representing banking or financial crisis. The sample period is from 1980 to 2018.

\subsubsection{Analysis of Panel Regressions: All-Countries Sample}

The results presented in Table 3 and Appendix A Table A3 are discussed separately, starting with the results of the all-countries sample presented in Table 3. Consistent with the model specified in Equation (2) and hypothesized signs, the coefficients for GRK and GRL are positive and significant in both the Panel Least Squares (Models 1-4) and the 
Panel Fully Modified Least Squares (Models 5-8) estimation methods. The GRL variable is statistically significant at $1 \%$ or $10 \%$ level, contributing more to GROWTH than GRK (statistically significance, $1 \%$ level). The coefficient for GOV, hypothesized to be either positive or negative, is positive and significant at the $1 \%$ level. These values are consistent with the contribution of government and the dominance of labor-intensive industries to growth in developing countries.

In Table 3, the coefficient for OPEN is positive, as expected, and statistically significant at the $1 \%$ level. BCD is negative, as expected, and statistically significant at either the $1 \%$ or $5 \%$ levels, consistent with other studies (Rousseau and Wachtel 2011). INF is also negative and significant, but this contradicts Botev et al. (2019) in their sample of worldwide countries. The results presented in Table 3 also show that, regardless of which proxy for financial development is used, estimated coefficients are positive and statistically significant at the $1 \%$ level in all cases, confirming a long-term positive relationship between financial development and economic growth in developing countries. The results are mostly consistent under both panel regression estimation methods, except for LL (Model 7) in the FMOLS method, which contradicts Hassan et al. (2011) and Guru and Yadav (2019). It is also important to state that the explanatory powers of the estimated models are very high, as evidenced by the Adjusted $\mathrm{R}^{2}$ exceeding 0.90 in each model.

\subsubsection{Analysis of Panel Regressions: East Asia and the Pacific}

The empirical results for East Asia and the Pacific region are presented in Panel A in Appendix A Table A3. As expected, GRK and GRL are positive and statistically significant at the 1\% level in both the Panel LS and FMOLS estimation methods, irrespective of the FD proxy employed; the results are better than the all-countries sample. GOV is also positive and significant (at the 1\% level), and while OPEN is positive, it has $1 \%$ significance only in three of the eight models. INF also has the expected negative sign, but it is statistically significant at the 1\% level only in the FMOLS estimation method, unlike in the all-countries sample. The coefficient for the banking crisis dummy (BCD), as expected, is negative and statistically significant either at the $1 \%, 5 \%$, or $10 \%$ level. The results also show that, regardless of which proxy for financial development is used, the estimated coefficient is positive and statistically significant at the $1 \%$ level of significance in all cases and, except for GDS, is mostly consistent with Hassan et al. (2011). Similar to the findings for the allcountries sample, this result confirms a long-term positive relationship between financial development and economic growth in developing countries in East Asia and the Pacific region. Finally, it is important that the explanatory powers of the estimated models are very high, as evidenced by the Adjusted $\mathrm{R}^{2}$ exceeding 0.84 in each model.

\subsubsection{Analysis of Panel Regressions: Europe and Central Asia}

The empirical results for the Europe and Central Asia region are presented in Panel B in Appendix A Table A3. As expected, the coefficients of GRK and GRL are positive and significant at the $1 \%$ or $5 \%$ level of significance, irrespective of the FD proxy used in both Panel LS and FMOLS. GOV and OPEN are positive and statistically significant in most of the models. INF has the expected negative sign and shows $1 \%$ significance levels under all FD proxies using the FMOLS estimation method, but not for DCBS when using the Panel LS method. BCD is negative and only statistically significant for models 2, 4, 7, and 8 , implying that the financial crisis may not have adversely affected this region as much as other regions, in comparison with the all-countries sample. The estimated coefficients of the financial development variables are positive and statistically significant at the $1 \%$ level of significance using all proxies. This result confirms the findings of Hassan et al. (2011) regarding the long-term positive relationship between financial development and economic growth in developing countries in Europe and Central Asia region but contradicts results by Destek et al. (2020). The explanatory powers of the estimated models are very high, as evidenced by the Adjusted $\mathrm{R}^{2}$ exceeding 0.89 in each model. Except for BCD, the results 
for Europe and Central Asia are similar to the all-countries sample and the East Asia and the Pacific region.

\subsubsection{Analysis of Panel Regressions: Latin America and the Caribbean}

The empirical results for the Latin America and the Caribbean region are presented in Panel C in Appendix A Table A3. GRK, GRL, and GOV are positive and significant the $1 \%$ level of significance, irrespective of the FD proxy used in both Panel LS and FMOLS, yielding better results than Europe and Central Asia and the all-countries sample. OPEN is also positive, as with Europe and Central Asia, but unlike East Asia and the Pacific, it is statistically significant in most of the models. The coefficient for the INF variable has the expected negative sign, and it is statistically significant at the either the $1 \%$ level or $5 \%$ level for all models and better than the results for the East Asia and the Pacific region. $\mathrm{BCD}$ also has the expected negative sign, and it is statistically significant at the $1 \%$ level of significance, which is higher than all regions and the all-countries sample. Similar to the results for the all-countries sample, the East Asia and the Pacific region, and the Europe and Central Asia region, the estimated coefficients of the financial development variables are positive and statistically significant at the $1 \%$ level of significance in all cases. Coinciding with Hassan et al. (2011), this result confirms a long-term positive relationship between financial development and economic growth in developing countries in the Latin America and the Caribbean region. The explanatory powers of the estimated models are very high, as evidenced by the Adjusted $\mathrm{R}^{2}$ exceeding 0.91 in each model.

\subsubsection{Analysis of Panel Regressions: Middle East and North Africa}

The empirical results for the Middle East and North Africa region are presented in Panel D in Appendix A Table A3. Unlike in the previous regions discussed, GRK is negative, contradicting our hypothesis, and statistically significant. GRL has the expected positive sign in Models 1-8, but it is not statistically significant in any of the models, meaning that population growth does not impact economic growth. GOV and OPEN are also positive and statistically significant in most of the models, in a similar manner to Latin America and the Caribbean, and better than the results for East Asia and the Pacific region but lower than for the all-countries sample. INF has the expected negative sign, but it is statistically significant only in three of the eight models, which is similar to East Asia and Pacific and Latin America and the Caribbean. BCD has the expected negative sign and is statistically significant at the $1 \%$ level of significance in all models, similar to the all-countries sample and Latin America and the Caribbean and higher than that of Europe and Central Asia. Paralleling the results for the all-countries sample and other regions, the estimated coefficients of the financial development variables are positive, but they are statistically significant only in five of the eight models. This result confirms a long-term positive relationship between financial development and economic growth in developing countries in the Middle East and North Africa, region corroborating Botev et al. (2019) and Hassan et al. (2011) but contradicting Yakubu et al. (2021). The explanatory powers of the estimated models, while high with an Adjusted $\mathrm{R}^{2}$ exceeding 0.80 in each model, are overall lower than the other regions and the all-countries sample.

\subsubsection{Analysis of Panel Regressions: South Asia}

The empirical results for the South Asia region are presented in Panel E in Appendix A Table A3. GRK, GRL, GOV, and OPEN are positive and significant at 5\% significance or higher irrespective of the FD proxy used in both PLS and FMOLS, yielding better results than Europe and Central Asia, MENA, and the all-countries sample. INF is negative but statistically significant at the $1 \%$ level under all FD proxies using the FMOLS estimation method but not for DCBS when using the PLS method, which is similar to Europe and Central Asia. BCD is negative and only significant in models 4, 5, 6, and 7, implying that the financial crisis may not have adversely affected this region (and Europe and Central Asia) as much as other regions, in comparison with the all-countries sample. Comparable 
to the results for the all-countries sample and the East Asia and the Pacific region, the estimated coefficients of the financial development variables are positive and statistically significant at the $1 \%$ level of significance in all cases. This result confirms a long-term positive relationship between financial development and economic growth in developing countries in the South Asia region, substantiating the results of Hsueh et al. (2013) and Hassan et al. (2011). The explanatory powers of the estimated models are very high, as evidenced by the Adjusted $\mathrm{R}^{2}$ exceeding 0.92 in each model.

\subsubsection{Analysis of Panel Regressions: Sub-Saharan Africa}

The empirical results for the Sub-Saharan Africa region are presented in Panel F in Appendix A Table A3. GRK and GRL are positive irrespective of the FD proxy used in both Panel Least Squares and FMOLS methods. However, while GRK is statistically significant at the $1 \%$ level of significance, as in every region other than the Middle East and North Africa, the GRL variable is statistically significant only in five of the eight models. GOV and OPEN are positive and statistically significant in all the models at the $1 \%$ or $5 \%$ level of significance. INF is negative but statistically significant at the $1 \%$ level under all FD proxies using the FMOLS estimation method, but not when using the Panel Least Squares method. BCD is negative and only significant in models $1,2,3$, and 7 , implying that the financial crisis may not have adversely affected this region, South Asia, and Europe and Central Asia as much as other regions, in comparison with the all-countries sample.

In Panel F of Appendix A Table A3, the estimated coefficients of the financial development variables are positive and statistically significant at the $1 \%$ level of significance when the models are estimated using the Panel Least Squares method. When the models are estimated using the FMOLS method, two of the models show a negative sign and statistically insignificant results. Nevertheless, results of the six out of eight models confirm a long-term positive relationship between financial development and economic growth in developing countries in the Sub-Saharan Africa region, substantiating the results of Ibrahim and Alagidede (2018) and Adu et al. (2013). The explanatory powers of the estimated models are very high, as evidenced by the Adjusted $\mathrm{R}^{2}$ exceeding 0.78 in each model but are lower than the other regions.

\subsection{Analysis of Panel Granger Causality}

The results of the panel Granger causality tests are presented in Table 4. The results are reported for each of the four financial development variables and for each of the geographic regions. GROWTH is said to Granger-cause a given financial development variable if it helps to predict GROWTH, or equivalently if the coefficients on the lagged financial development variable are statistically significant.

The results presented in Panel A of Table 4 show that the F-statistic is statistically significant in Europe and Central Asia, South Asia, and the all-countries sample, rejecting the null hypothesis that DCPS does not Granger-cause GROWTH. These results corroborate Hsueh et al. (2013) and Hassan et al. (2011). The results also show that the F-statistic is statistically significant in all geographic regions, rejecting the null hypothesis that that GROWTH does not Granger-cause DCPS, which differs from the results of Hsueh et al. (2013), who find no significance in the case of their sample of Asian countries. Thus, there is evidence of bi-directional causality running from DCPS to GROWTH and from GROWTH to DCPS in Europe and Central Asia, South Asia, and the all-countries sample, confirming unidirectional causality running from GROWTH to DCPS in East Asia and the Pacific, Latin America and the Caribbean, Middle East and North Africa, and Sub-Saharan Africa. These results are similar to other studies' findings in other regions or countries (Hassan et al. 2011).

Similar to Panel A, the results in Panel B of Table 4 show statistical significance in Europe and Central Asia, South Asia, and the all-countries sample, rejecting the null hypothesis that DCBS does not Granger-cause GROWTH. However, in Sub-Saharan Africa, DCBS does not Granger-cause GROWTH. This reinforces the findings of Adu et al. (2013). 
The results also reveal that GROWTH Granger-causes DCBS in all geographic regions except the Middle East and North Africa region. Thus, there is evidence of bi-directional causality running from DCBS to GROWTH and from GROWTH to DCBS in Europe and Central Asia, South Asia, and the all-countries sample, and unidirectional causality running from GROWTH to DCBS in East Asia and the Pacific, Latin America and the Caribbean, and Sub-Saharan Africa.

Table 4. Panel Granger causality tests.

\begin{tabular}{|c|c|c|c|c|c|c|}
\hline \multicolumn{7}{|c|}{ Panel A: Granger Causality between DCPS and GROWTH } \\
\hline & \multicolumn{3}{|c|}{$H_{0}:$ DCPS Does Not Granger Cause GROWTH } & \multicolumn{3}{|c|}{$H_{0}:$ GROWTH Does Not Granger Cause DCPS } \\
\hline Region & Obs. & F-Statistic & $p$-Value & Obs. & F-Statistic & p-Value \\
\hline East Asia and Pacific & 623 & 2.11 & 0.1216 & 623 & $5.77^{* * *}$ & 0.0033 \\
\hline Europe and Central Asia & 450 & $2.94 *$ & 0.0537 & 450 & $4.78^{* * *}$ & 0.0088 \\
\hline Latin America and Caribbean & 1175 & 0.13 & 0.8800 & 1175 & $4.16^{* *}$ & 0.0159 \\
\hline Middle East and North Africa & 517 & 0.13 & 0.8739 & 517 & $3.94 * *$ & 0.0200 \\
\hline South Asia & 258 & $4.59 * *$ & 0.0110 & 258 & $4.44^{* *}$ & 0.0128 \\
\hline Sub-Saharan Africa & 1529 & 1.06 & 0.3474 & 1529 & $5.12 * * *$ & 0.0061 \\
\hline All-countries sample & 4552 & $2.84 *$ & 0.0588 & 4552 & $20.95^{* * *}$ & 0.0001 \\
\hline \multicolumn{7}{|c|}{ Panel B: Granger Causality between $D C B S$ and GROWTH } \\
\hline & \multicolumn{3}{|c|}{$H_{0}:$ DCBS Does Not Granger Cause GROWTH } & \multicolumn{3}{|c|}{$H_{0}:$ GROWTH Does Not Granger Cause DCBS } \\
\hline Region & Obs. & F-Statistic & p-Value & Obs. & F-Statistic & p-Value \\
\hline East Asia and Pacific & 604 & 2.30 & 0.1006 & 604 & $13.83^{* * *}$ & 0.0001 \\
\hline Europe and Central Asia & 453 & $11.34^{* * *}$ & 0.0001 & 453 & $10.64^{* * *}$ & 0.0001 \\
\hline Latin America and Caribbean & 1215 & 1.35 & 0.2586 & 1215 & $7.96^{* * *}$ & 0.0004 \\
\hline Middle East and North Africa & 506 & 1.06 & 0.9442 & 506 & 2.16 & 0.1161 \\
\hline South Asia & 256 & $3.36^{* *}$ & 0.0364 & 256 & $4.12^{* *}$ & 0.0173 \\
\hline Sub-Saharan Africa & 1455 & 1.02 & 0.3627 & 1455 & $8.84^{* * *}$ & 0.0002 \\
\hline All-countries sample & 4489 & $2.63 *$ & 0.0720 & 4489 & $36.74^{* * *}$ & 0.0001 \\
\hline \multicolumn{7}{|c|}{ Panel C: Granger Causality between $L L$ and $G R O W T H$} \\
\hline & \multicolumn{3}{|c|}{$H_{0}:$ LL Does Not Granger Cause GROWTH } & \multicolumn{3}{|c|}{$H_{0}:$ GROWTH Does Not Granger Cause LL } \\
\hline Region & Obs. & F-Statistic & $p$-Value & Obs. & F-Statistic & $p$-Value \\
\hline East Asia and Pacific & 604 & $4.59 * *$ & 0.0105 & 604 & $4.43^{* * *}$ & 0.0123 \\
\hline Europe and Central Asia & 453 & $6.75^{* * *}$ & 0.0013 & 453 & $30.24 * * *$ & 0.0001 \\
\hline Latin America and Caribbean & 1215 & 0.52 & 0.5971 & 1215 & 1.65 & 0.1930 \\
\hline Middle East and North Africa & 517 & $13.60 * * *$ & 0.0001 & 517 & $3.22 * *$ & 0.0406 \\
\hline South Asia & 258 & $2.37 *$ & 0.0958 & 258 & 1.84 & 0.1605 \\
\hline Sub-Saharan Africa & 1451 & 1.92 & 0.1464 & 1451 & 2.19 & 0.1126 \\
\hline All-countries sample & 4498 & $39.33^{* * *}$ & 0.0001 & 4498 & $22.50 * * *$ & 0.0001 \\
\hline \multicolumn{7}{|c|}{ Panel D: Granger Causality between GDS and GROWTH } \\
\hline & \multicolumn{3}{|c|}{$H_{0}:$ LL Does Not Granger Cause GROWTH } & \multicolumn{3}{|c|}{$H_{0}:$ GROWTH Does Not GRANGER Cause LL } \\
\hline Region & Obs. & F-Statistic & $p$-Value & Obs. & F-Statistic & p-Value \\
\hline East Asia and Pacific & 622 & 1.71 & 0.1875 & 622 & 1.08 & 0.9257 \\
\hline Europe and Central Asia & 560 & $7.26^{* * *}$ & 0.0008 & 453 & $18.00 * * *$ & 0.0001 \\
\hline Latin America and Caribbean & 1215 & $8.54^{* * *}$ & 0.0002 & 1215 & $2.91 *$ & 0.0546 \\
\hline Middle East and North Africa & 518 & 1.56 & 0.2110 & 518 & 1.23 & 0.7957 \\
\hline South Asia & 258 & $6.63 * * *$ & 0.0016 & 258 & 2.07 & 0.1288 \\
\hline Sub-Saharan Africa & 1529 & 1.54 & 0.4194 & 1529 & $4.10^{* *}$ & 0.1126 \\
\hline All-countries sample & 4702 & $2.53 *$ & 0.0794 & 4702 & $18.38^{* * *}$ & 0.0167 \\
\hline
\end{tabular}

Note: This table shows the results of the panel Granger causality tests. It presents F-statistics and $p$-values as well as the number of observations in each panel or economic growth determinants. The signs ***,**, and * indicate statistical significance of F-statistic at $1 \%, 5 \%$, and $10 \%$ levels, respectively. GROWTH is the growth rate of real GDP per capita; DCPS is the domestic credit provided to the private sector as a share of GDP; DCBS is the domestic credit provided by banking sector as a share of GDP; LL is the liquid liabilities as a share of GDP; and GDS is the gross domestic savings as a share of GDP. The sample period is from 1980 to 2018.

Panel C of Table 4 shows statistically significant results in East Asia and the Pacific, Europe and Central Asia, Middle East and North Africa, South Asia, and the all-countries sample, rejecting the null hypothesis that LL does not Granger-cause GROWTH. This is not the case for Sub-Saharan Africa and Latin America and the Caribbean. Results also reveal statistical significance in East Asia and the Pacific, Europe and Central Asia, Middle East and North Africa, and the all-countries sample, rejecting the null hypothesis that that GROWTH does not Granger-cause LL. Thus, there is evidence of bi-directional causality running from LL to GROWTH and from GROWTH to LL in East Asia and the Pacific, 
Europe and Central Asia, Middle East and North Africa, and the all-countries sample, and unidirectional causality running from LL to GROWTH in South Asia. Sub-Saharan Africa and Latin America and the Caribbean show no causality, bolstering other studies' results.

Panel D of Table 4 shows statistically significant results in Europe and Central Asia, Latin America and the Caribbean, Sub-Saharan Africa, and the all-countries sample, rejecting the null hypothesis that GDS does not Granger-cause GROWTH. Similarly, the statistical significance in Europe and Central Asia, Latin America and the Caribbean, SubSaharan Africa, and the all-countries sample rejects the null hypothesis that GROWTH does not Granger-cause GDS. Thus, there is evidence of bi-directional causality running from GDS to GROWTH and from GROWTH to GDS in Europe and Central Asia, Latin America and the Caribbean, and the all-countries sample, as well as unidirectional causality running from GDS to GROWTH in South Asia and unidirectional causality running from GROWTH to GDS in Sub-Saharan Africa. MENA countries show no causality.

Thus, regardless of which measure of financial development (FD) is used, there is evidence of bi-directional causality running from FD to GROWTH and from GROWTH to FD in Europe and Central Asia, South Asia, and the all-countries sample, but not for the other regions. These results are supported by those of Botev et al. (2019), Guru and Yadav (2019), and Ibrahim and Alagidede (2018).

\section{Summary, Conclusions, and Future Studies}

This study investigates the nexus between financial development and economic growth in developing countries. The study uses a panel data covering 138 developing countries during the period 1980-2018. We have separated 138 countries into six geographic regions, and models were estimated for each of the regions in addition to estimating them in a pooled all-countries sample. Since the data on some of the variables were missing for some countries for some years, the models were estimated using an unbalanced panel.

Before estimating the specified models, all variables were tested for panel unit-roots before carrying out panel cointegration tests. Panel unit-root tests confirmed that all the variables are stationary at the first difference. We have utilized three different methods of testing the panel cointegration: namely, Pedroni's Heterogeneous Panel Cointegration Test, the Johansen-Fisher Panel Cointegration Test, and the Kao Residual Panel Cointegration Test. The panel cointegration tests show clear evidence of cointegration among seven variables for all geographic regions, regardless of which measure of financial development is used.

The specified model was estimated using two estimation methods: namely, Panel LS and Panel FMOLS. Results indicate that, for both estimation methods, GRK is significant for the all-countries pooled sample, as well as for each region. GRL is significant for all countries, as well as for all regions, except for MENA and SSA. GOV is significant for all countries and all regions, except for MENA, where the Panel FMOLS shows no significance. OPEN is not significant for all countries or all regions, except for the Middle East and North Africa and Sub-Saharan Africa, which show significance irrespective of the estimation models. The results also show that, regardless of which proxy for financial development is used, the estimated coefficient is positive and statistically significant at the $1 \%$ level of significance in four regions and the all-countries sample, confirming a long-term positive relationship between financial development and economic growth. The Middle East and North Africa and Sub-Saharan Africa are exceptions; in the case of the former, the Panel LS model shows DCBS, LL, and GDS are not significant, whereas in Sub-Saharan Africa, the Panel FMOLS model shows DCPS and DCBS are not significant. South Asia shows significance for all independent variables, except for BCD, revealing that the financial crisis had very little-if any-effect on growth. In addition, in either of the two estimation models, the financial/banking crisis had an insignificant effect on growth in Sub-Saharan Africa, Latin America and Caribbean, and Europe and Central Asia.

The results of the panel Granger causality tests show that, regardless of which measure of financial development (FD) is used, there is evidence of bi-directional causality running from FD to GROWTH and from GROWTH to FD in Europe and Central Asia, South Asia, 
and the all-countries sample. The East Asia and the Pacific region shows one-way causality from growth to FD, except when GDS is used as a FD proxy. The Latin America and the Caribbean region shows one-way causality from growth to FD, except when LL is used as a proxy for FD. In the Middle East and North Africa region, it is shown that growth does not Granger-cause DCBS and LL. In Sub-Saharan Africa, it is revealed that growth does not Granger-cause LL.

Our results indicate that policies to enhance gross domestic savings and the availability of liquid liabilities in Sub-Saharan Africa and the Middle East and North Africa may allow for greater economic growth.

The proxy variables for financial development are numerous. A future study could focus on developing an index of financial development by combining such proxy variables. This paper does not also consider the stock and bond markets, even though other studies have demonstrated that they play key roles in a country's financial development and economic growth and therefore should be considered in future studies. In addition, poverty and inequality are prevalent in developing countries, particularly in Sub-Saharan Africa, and therefore should be considered in future studies.

Author Contributions: Conceptualization, E.M.E. and R.T.; methodology, E.M.E.; software, E.M.E.; validation, E.M.E. and R.T.; formal analysis, E.M.E. and R.T.; investigation, E.M.E. and R.T.; resources, E.M.E. and R.T.; data curation, E.M.E.; writing—original draft preparation, E.M.E. and R.T.; writingreview and editing, E.M.E. and R.T.; visualization, E.M.E. and R.T.; supervision, Not applicable; project administration, Not applicable; funding acquisition, Not applicable. All authors have read and agreed to the published version of the manuscript.

Funding: This research received no external funding.

Institutional Review Board Statement: Not applicable.

Informed Consent Statement: Not applicable.

Data Availability Statement: Not applicable.

Conflicts of Interest: The authors declare no conflict of interest.

\section{Appendix A}

Table A1. Pedroni's Heterogeneous Panel Cointegration Tests.

\begin{tabular}{|c|c|c|c|c|c|c|c|}
\hline \multicolumn{8}{|c|}{ Panel A: Series: GROWTH, GRK, GRL, OPEN, GOV, INF, DCPS } \\
\hline \multirow[b]{2}{*}{ Region } & \multicolumn{4}{|c|}{$\begin{array}{c}\text { Panel Cointegration Statistics } \\
\text { (Within-Dimension) }\end{array}$} & \multicolumn{3}{|c|}{$\begin{array}{l}\text { Panel Cointegration Statistics } \\
\text { (Between-Dimension) }\end{array}$} \\
\hline & $\begin{array}{c}\text { Panel } \\
\text { v-Statistic }\end{array}$ & $\begin{array}{c}\text { Panel } \\
\rho-\text { Statistic }\end{array}$ & $\begin{array}{c}\text { Panel } \\
\text { PP-Statistic }\end{array}$ & $\begin{array}{c}\text { Panel } \\
\text { ADF-Statistic }\end{array}$ & $\underset{\rho-S t a t i s t i c}{\text { Group }}$ & $\begin{array}{c}\text { Group } \\
\text { PP-Statistic }\end{array}$ & $\begin{array}{c}\text { Group } \\
\text { ADF-Statistic }\end{array}$ \\
\hline East Asia and & 0.46 & $-1.48 *$ & $-6.77^{* * *}$ & $-7.26^{* * *}$ & $-1.56^{* *}$ & $-9.60 * * *$ & $-8.72 * * *$ \\
\hline Pacific & $(0.249)$ & $(0.069)$ & $(0.000)$ & $(0.000)$ & $(0.052)$ & $(0.000)$ & $(0.000)$ \\
\hline Europe and & 0.22 & -0.78 & $-4.72 * * *$ & $-4.80^{* * *}$ & $-1.42 *$ & $-12.08^{* * *}$ & $-10.54^{* * *}$ \\
\hline Central Asia & $(0.369)$ & $(0.785)$ & $(0.000)$ & $(0.000)$ & $(0.072)$ & $(0.000)$ & $(0.000)$ \\
\hline Latin America & 0.38 & $-3.33^{* * *}$ & $-16.84^{* * *}$ & $-16.10^{* * *}$ & -1.18 & $-21.75^{* * *}$ & $-17.48^{* * *}$ \\
\hline \& Caribbean & $(0.351)$ & $(0.000)$ & $(0.000)$ & $(0.000)$ & $(0.119)$ & $(0.000)$ & $(0.000)$ \\
\hline Middle East & 0.18 & $-1.71 * *$ & $-9.08^{* * *}$ & $-9.42 * * *$ & $-2.22 * *$ & $-12.71^{* * *}$ & $-12.86^{* * *}$ \\
\hline and N. Africa & $(0.435)$ & $(0.043)$ & $(0.000)$ & $(0.000)$ & $(0.013)$ & $(0.000)$ & $(0.000)$ \\
\hline \multirow{2}{*}{ South Asia } & 0.52 & -1.23 & $-11.42^{* * *}$ & $-8.18^{* * *}$ & $-1.76^{* *}$ & $-14.57^{* * *}$ & $-11.22^{* * *}$ \\
\hline & $(0.179)$ & $(0.108)$ & $(0.000)$ & $(0.000)$ & $(0.038)$ & $(0.000)$ & $(0.000)$ \\
\hline Sub-Saharan & 0.39 & -0.38 & $-18.88^{* * *}$ & $-15.71^{* * *}$ & $-1.55^{*}$ & $-25.46^{* * *}$ & $-19.15^{* * *}$ \\
\hline Africa & $(0.342)$ & $(0.356)$ & $(0.000)$ & $(0.000)$ & $(0.060)$ & $(0.000)$ & $(0.000)$ \\
\hline \multirow{2}{*}{ All Countries } & 0.53 & $-3.79 * * *$ & $-24.05^{* * *}$ & $-25.83^{* * *}$ & $-2.28 * *$ & $-34.88^{* * *}$ & $-29.22^{* * *}$ \\
\hline & $(0.182)$ & $(0.000)$ & $(0.000)$ & $(0.000)$ & $(0.011)$ & $(0.000)$ & (0.000) \\
\hline
\end{tabular}


Table A1. Cont.

\begin{tabular}{|c|c|c|c|c|c|c|c|}
\hline \multicolumn{8}{|c|}{ Panel B: Series: GROWTH, GRK, GRL, OPEN, GOV, INF, DCBS } \\
\hline \multirow[b]{2}{*}{ Region } & \multicolumn{4}{|c|}{$\begin{array}{l}\text { Panel Cointegration Statistics } \\
\text { (Within-Dimension) }\end{array}$} & \multicolumn{3}{|c|}{$\begin{array}{l}\text { Panel Cointegration Statistics } \\
\text { (Between-Dimension) }\end{array}$} \\
\hline & $\begin{array}{c}\text { Panel } \\
\text { v-Statistic }\end{array}$ & $\begin{array}{c}\text { Panel } \\
\rho-\text { Statistic }\end{array}$ & $\begin{array}{c}\text { Panel } \\
\text { PP-Statistic }\end{array}$ & $\begin{array}{c}\text { Panel } \\
\text { ADF-Statistic }\end{array}$ & $\begin{array}{c}\text { Group } \\
\rho \text {-Statistic }\end{array}$ & $\begin{array}{c}\text { Group } \\
\text { PP-Statistic }\end{array}$ & $\begin{array}{c}\text { Group } \\
\text { ADF-Statistic }\end{array}$ \\
\hline East Asia and & 0.48 & $-1.57 *$ & $-7.07^{* * *}$ & $-7.58^{* * *}$ & -1.10 & $-10.27^{* * *}$ & $-9.44^{* * *}$ \\
\hline Pacific & $(0.241)$ & $(0.059)$ & $(0.000)$ & $(0.000)$ & $(0.137)$ & $(0.000)$ & $(0.000)$ \\
\hline Europe and & 0.22 & -0.98 & $-5.57 * * *$ & $-6.75^{* * *}$ & $-1.44 *$ & $-12.65^{* * *}$ & $-9.70^{* * *}$ \\
\hline Central Asia & $(0.369)$ & $(0.655)$ & $(0.000)$ & $(0.000)$ & $(0.071)$ & $(0.000)$ & $(0.000)$ \\
\hline Latin America & 0.42 & $-3.02 * * *$ & $-15.27^{* * *}$ & $-15.26^{* * *}$ & $-1.41 *$ & $-18.66^{* * *}$ & $-15.87^{* * *}$ \\
\hline \& Caribbean & $(0.333)$ & $(0.001)$ & $(0.000)$ & $(0.000)$ & $(0.078)$ & $(0.000)$ & $(0.000)$ \\
\hline Middle East & 0.27 & $-1.83^{* *}$ & $-9.24 * * *$ & $-9.44^{* * *}$ & $-1.96^{* *}$ & $-13.36^{* * *}$ & $-12.84^{* * *}$ \\
\hline and N. Africa & $(0.414)$ & $(0.033)$ & $(0.000)$ & $(0.000)$ & $(0.025)$ & $(0.000)$ & $(0.000)$ \\
\hline South Asia & 0.54 & $-2.25^{* *}$ & $-11.16^{* * *}$ & $-7.73^{* * *}$ & $-1.48^{*}$ & $-14.17^{* * *}$ & $-10.91^{* * *}$ \\
\hline south Assa & $(0.173)$ & $(0.249)$ & $(0.000)$ & $(0.000)$ & $(0.069)$ & $(0.000)$ & $(0.000)$ \\
\hline Sub-Saharan & 0.42 & $-2.47^{* *}$ & $-19.04^{* * *}$ & $-15.00^{* * *}$ & $-1.54 *$ & $-24.55^{* * *}$ & $-19.41^{* * *}$ \\
\hline Africa & $(0.339)$ & $0.000)$ & $(0.000)$ & $(0.000)$ & $(0.063)$ & $(0.000)$ & $(0.000)$ \\
\hline All Countries & $\begin{array}{c}0.56 \\
(0.162)\end{array}$ & $\begin{array}{l}-5.53^{* * *} \\
(0.000)\end{array}$ & $\begin{array}{l}-24.77^{* * *} \\
(0.000)\end{array}$ & $\begin{array}{l}-24.41^{* * *} \\
(0.000)\end{array}$ & $\begin{array}{l}-2.05^{* *} \\
(0.019)\end{array}$ & $\begin{array}{c}-34.09 * * * \\
(0.000)\end{array}$ & $\begin{array}{l}-28.24^{* * *} \\
(0.000)\end{array}$ \\
\hline \multicolumn{8}{|c|}{ Panel C: Series: GROWTH, GRK, GRL, OPEN, GOV, INF, LL } \\
\hline & \multicolumn{4}{|c|}{$\begin{array}{l}\text { Panel Cointegration Statistics } \\
\text { (Within-Dimension) }\end{array}$} & \multicolumn{3}{|c|}{$\begin{array}{l}\text { Panel Cointegration Statistics } \\
\text { (Between-Dimension) }\end{array}$} \\
\hline Region & $\begin{array}{c}\text { Panel } \\
\text { v-Statistic }\end{array}$ & $\begin{array}{c}\text { Panel } \\
\rho \text {-Statistic }\end{array}$ & $\begin{array}{c}\text { Panel } \\
\text { PP-Statistic }\end{array}$ & $\begin{array}{c}\text { Panel } \\
\text { ADF-Statistic }\end{array}$ & $\begin{array}{c}\text { Group } \\
\rho \text {-Statistic }\end{array}$ & $\begin{array}{c}\text { Group } \\
\text { PP-Statistic }\end{array}$ & $\begin{array}{c}\text { Group } \\
\text { ADF-Statistic }\end{array}$ \\
\hline East Asia and & 0.55 & $-1.38 *$ & $-7.85^{* * *}$ & $-7.76^{* * *}$ & $-1.54 * *$ & $-9.87^{* * *}$ & $-8.99 * * *$ \\
\hline Pacific & $(0.234)$ & $(0.084)$ & $(0.000)$ & $(0.000)$ & $(0.058)$ & $(0.000)$ & $(0.000)$ \\
\hline Europe and & 0.22 & -0.79 & $-7.62^{* * *}$ & $-6.68^{* * *}$ & $-1.43 *$ & $-12.50 * * *$ & $-8.41^{* * *}$ \\
\hline Central Asia & $(0.369)$ & $(0.782)$ & $(0.000)$ & $(0.000)$ & $(0.071)$ & $(0.000)$ & $(0.000)$ \\
\hline Latin America & 0.44 & $-3.07^{* * *}$ & $-15.16^{* * *}$ & $-15.21^{* * *}$ & -1.54 * & $-17.75^{* * *}$ & $-15.64^{* * *}$ \\
\hline \& Caribbean & $(0.321)$ & $(0.001)$ & $(0.000)$ & $(0.000)$ & $(0.061)$ & $(0.000)$ & $(0.000)$ \\
\hline Middle East & 0.32 & $-1.41 *$ & $-9.41 * * *$ & $-9.63^{* * *}$ & $-1.42 *$ & $-12.02 * * *$ & $-11.84^{* * *}$ \\
\hline and N. Africa & $(0.407)$ & $(0.081)$ & $(0.000)$ & $(0.000)$ & $(0.077)$ & $(0.000)$ & $(0.000)$ \\
\hline South Asia & 0.51 & $-1.50 *$ & $-11.49^{* * *}$ & $-8.20 * * *$ & $-1.68^{* *}$ & $-14.37^{* * *}$ & $-11.06^{* * *}$ \\
\hline & $(0.181)$ & $(0.066)$ & $(0.000)$ & $(0.000)$ & $(0.046)$ & $(0.000)$ & $(0.000)$ \\
\hline Sub-Saharan & 0.47 & $-1.99 * *$ & $-12.92^{* * *}$ & $-12.61^{* * *}$ & $-1.56 *$ & $-23.52^{* * *}$ & $-18.43^{* * *}$ \\
\hline Africa & $(0.332)$ & $(0.022)$ & $(0.000)$ & $(0.000)$ & $(0.058)$ & $(0.000)$ & $(0.000)$ \\
\hline All Countries & $\begin{array}{c}0.62 \\
(0.134)\end{array}$ & $\begin{array}{l}-6.35^{* * *} \\
(0.000)\end{array}$ & $\begin{array}{c}-25.37^{* * *} \\
(0.000)\end{array}$ & $\begin{array}{c}-24.53^{* * *} \\
(0.000)\end{array}$ & $\begin{array}{l}-2.29 * * \\
(0.011)\end{array}$ & $\begin{array}{c}-35.68^{* * *} \\
(0.000)\end{array}$ & $\begin{array}{c}-28.36^{* * *} \\
(0.000)\end{array}$ \\
\hline
\end{tabular}

Note: This table shows the results of the Pedroni's Heterogeneous Panel Cointegration Test. Of the seven tests, the panel v-statistic is a one-sided test where large positive values reject the null hypothesis of no cointegration whereas large negative values for the remaining test statistics reject the null hypothesis of no cointegration. The number of lag length was selected automatically based on SIC with a maximum lag of 8 . The figures in the parentheses are $p$-values. The signs ${ }^{* * * * *}$, and ${ }^{*}$ indicate statistical significance of the test statistic at $1 \%, 5 \%$, and $10 \%$ levels, respectively. 
Table A2. Kao Residual Panel Cointegration Tests.

\begin{tabular}{|c|c|c|}
\hline \multicolumn{3}{|c|}{ Panel A: Series: GROWTH, GRK, GRL, GOV, OPEN, INF, DCPS } \\
\hline \multirow[b]{2}{*}{ Region } & \multicolumn{2}{|c|}{$H_{0}:$ No Cointegration } \\
\hline & $t$-Statistic & $p$-Value \\
\hline East Asia and Pacific & $-9.93^{* * *}$ & 0.0001 \\
\hline Europe and Central Asia & $-8.57^{* * *}$ & 0.0001 \\
\hline Latin America and the Caribbean & $-14.24^{* * *}$ & 0.0001 \\
\hline Middle East and North Africa & $-12.45^{* * *}$ & 0.0001 \\
\hline South Asia & $-9.90^{* * *}$ & 0.0001 \\
\hline Sub-Saharan Africa & $-8.32^{* * *}$ & 0.0001 \\
\hline All Countries & $-28.09 * * *$ & 0.0001 \\
\hline \multicolumn{3}{|c|}{ Panel B: Series: GROWTH, GRK, GRL, GOV, OPEN, INF, DCBS } \\
\hline & \multicolumn{2}{|c|}{$H_{0}:$ No Cointegration } \\
\hline Region & t-Statistic & p-Value \\
\hline East Asia and Pacific & $-9.42^{* * *}$ & 0.0001 \\
\hline Europe and Central Asia & $-10.26^{* * *}$ & 0.0001 \\
\hline Latin America and the Caribbean & $-13.46^{* * *}$ & 0.0001 \\
\hline Middle East and North Africa & $-13.42^{* * *}$ & 0.0001 \\
\hline South Asia & $-9.54^{* * *}$ & 0.0001 \\
\hline Sub-Saharan Africa & $-8.45^{* * *}$ & 0.0001 \\
\hline All Countries & $-28.09 * * *$ & 0.0001 \\
\hline \multicolumn{3}{|c|}{ Panel C: Series: GROWTH, GRK, GRL, GOV, OPEN, INF, LL } \\
\hline & \multicolumn{2}{|c|}{$H_{0}:$ No Cointegration } \\
\hline Region & $t$-Statistic & $p$-Value \\
\hline East Asia and Pacific & $-9.90^{* * *}$ & 0.0001 \\
\hline Europe and Central Asia & $-9.22^{* * *}$ & 0.0001 \\
\hline Latin America and the Caribbean & $-15.95^{* * *}$ & 0.0001 \\
\hline Middle East and North Africa & $-15.39^{* * *}$ & 0.0001 \\
\hline South Asia & $-10.29 * * *$ & 0.0001 \\
\hline Sub-Saharan Africa & $-9.19^{* * *}$ & 0.0001 \\
\hline All Countries & $-28.09^{* * *}$ & 0.0001 \\
\hline \multicolumn{3}{|c|}{ Panel D: Series: GROWTH, GRK, GRL, GOV, OPEN, INF, GDS } \\
\hline & \multicolumn{2}{|c|}{$H_{0}:$ No Cointegration } \\
\hline Region & $t$-Statistic & p-Value \\
\hline East Asia and Pacific & $-8.72 * * *$ & 0.0001 \\
\hline Europe and Central Asia & $-9.62 * * *$ & 0.0001 \\
\hline Latin America and the Caribbean & $-11.12^{* * *}$ & 0.0001 \\
\hline Middle East and North Africa & $-12.51 * * *$ & 0.0001 \\
\hline South Asia & $-9.41^{* * *}$ & 0.0001 \\
\hline Sub-Saharan Africa & $-8.57^{* * *}$ & 0.0001 \\
\hline All Countries & $-22.53^{* * *}$ & 0.0001 \\
\hline
\end{tabular}

Note: This table shows the results Kao residual panel cointegration test. It tests the null hypothesis of no cointegration. The table reports both the t-statistic and $p$-values. The sign ${ }^{* * *}$ indicates statistical significance of t-statistic at the $1 \%$ level. 
Table A3. Economic growth regressions for geographic regions.

\begin{tabular}{|c|c|c|c|c|c|c|c|c|}
\hline \multicolumn{9}{|c|}{ Panel A: East Asia and Pacific } \\
\hline \multirow{2}{*}{ Variable } & \multicolumn{4}{|c|}{ Panel Least Squares } & \multicolumn{4}{|c|}{ Panel Fully Modified Least Squares (FMOLS) } \\
\hline & Model 1 & Model 2 & Model 3 & Model 4 & Model 5 & Model 6 & Model 7 & Model 8 \\
\hline Constant & $\begin{array}{c}7.0358^{* * *} \\
(0.0001)\end{array}$ & $\begin{array}{c}7.1000 * * * \\
(0.0001)\end{array}$ & $\begin{array}{c}6.8012^{* * *} \\
(0.0001)\end{array}$ & $\begin{array}{c}6.9431^{* * *} \\
(0.0001)\end{array}$ & & & & \\
\hline$G R K$ & $\begin{array}{c}0.0115^{* * *} \\
(0.0003)\end{array}$ & $\begin{array}{c}0.0108^{* * *} \\
(0.0001)\end{array}$ & $\begin{array}{c}0.0091^{* * *} \\
(0.0004)\end{array}$ & $\begin{array}{c}0.0118^{* * *} \\
(0.0001)\end{array}$ & $\begin{array}{c}0.0084^{* * *} \\
(0.0001)\end{array}$ & $\begin{array}{c}0.0061^{* * *} \\
(0.0002)\end{array}$ & $\begin{array}{c}0.0093^{* * *} \\
(0.0001)\end{array}$ & $\begin{array}{c}0.0092^{* * *} \\
(0.0004)\end{array}$ \\
\hline$G R L$ & $\begin{array}{c}0.0366^{* * *} \\
(0.0019)\end{array}$ & $\begin{array}{c}0.0369 * * * \\
(0.0064)\end{array}$ & $\begin{array}{c}0.0273 * * * \\
(0.0092)\end{array}$ & $\begin{array}{c}0.0326^{* * *} \\
(0.0004)\end{array}$ & $\begin{array}{c}0.0325^{* * *} \\
(0.0010)\end{array}$ & $\begin{array}{c}0.0369 * * * \\
(0.0019)\end{array}$ & $\begin{array}{c}0.0337^{* * *} \\
(0.0095)\end{array}$ & $\begin{array}{c}0.1443^{* * *} \\
(0.0001)\end{array}$ \\
\hline GOV & $\begin{array}{c}0.0118^{* * *} \\
(0.0015)\end{array}$ & $\begin{array}{c}0.0163^{* * *} \\
(0.0004)\end{array}$ & $\begin{array}{c}0.0193^{* * *} \\
(0.0005)\end{array}$ & $\begin{array}{c}0.0190^{* * *} \\
(0.0001)\end{array}$ & $\begin{array}{c}0.0151^{* * *} \\
(0.0001)\end{array}$ & $\begin{array}{c}0.0327 * * * \\
(0.0001)\end{array}$ & $\begin{array}{c}0.0307^{* * *} \\
(0.0001)\end{array}$ & $\begin{array}{c}0.0340 * * * \\
(0.0001)\end{array}$ \\
\hline OPEN & $\begin{array}{c}0.0012 \\
(0.4405)\end{array}$ & $\begin{array}{c}0.0003 \\
(0.4754)\end{array}$ & $\begin{array}{c}0.0004 \\
(0.2923)\end{array}$ & $\begin{array}{c}0.0034^{* * *} \\
(0.0001)\end{array}$ & $\begin{array}{c}0.0018^{* * *} \\
(0.0001)\end{array}$ & $\begin{array}{c}0.0012 \\
(0.1088)\end{array}$ & $\begin{array}{c}0.0017 \\
(0.2336)\end{array}$ & $\begin{array}{c}0.0024^{* * *} \\
(0.0001)\end{array}$ \\
\hline$I N F$ & $\begin{array}{c}-0.0003 \\
(0.4326)\end{array}$ & $\begin{array}{l}-0.0003 \\
(0.4480)\end{array}$ & $\begin{array}{l}-0.0003 \\
(0.4339)\end{array}$ & $\begin{array}{l}-0.0007 \\
(0.2395)\end{array}$ & $\begin{array}{c}-0.0013^{* * *} \\
(0.0010)\end{array}$ & $\begin{array}{c}-0.0020^{* * *} \\
(0.0022)\end{array}$ & $\begin{array}{c}-0.0015^{* * *} \\
(0.0019)\end{array}$ & $\begin{array}{c}-0.0039 * * * \\
(0.0001)\end{array}$ \\
\hline$B C D$ & $\begin{array}{c}-0.1198 * * * \\
(0.0005)\end{array}$ & $\begin{array}{c}-0.1716 \text { *** } \\
(0.0047)\end{array}$ & $\begin{array}{c}-0.0705 * \\
(0.0732)\end{array}$ & $\begin{array}{c}-0.0797 * * \\
(0.0236)\end{array}$ & $\begin{array}{c}-0.1112 * * * \\
(0.0019)\end{array}$ & $\begin{array}{c}-0.1822 \text { *** } \\
(0.0001)\end{array}$ & $\begin{array}{c}-0.07311^{* *} \\
(0.0388)\end{array}$ & $\begin{array}{c}-0.0484 \text { *** } \\
(0.0002)\end{array}$ \\
\hline$D C P S$ & $\begin{array}{c}0.0111^{* * *} \\
(0.0001)\end{array}$ & & & & $\begin{array}{c}0.0128 * * * \\
(0.0001)\end{array}$ & & & \\
\hline$D C B S$ & & $\begin{array}{c}0.0104^{* * *} \\
(0.0001)\end{array}$ & & & & $\begin{array}{c}0.0085^{* * *} \\
(0.0001)\end{array}$ & & \\
\hline$L L$ & & & $\begin{array}{c}0.0105^{* * *} \\
(0.0001)\end{array}$ & & & & $\begin{array}{c}0.0095^{* * *} \\
(0.0001)\end{array}$ & \\
\hline GDS & & & & $\begin{array}{c}0.0111^{* * *} \\
(0.0001)\end{array}$ & & & & $\begin{array}{c}0.0183^{* * *} \\
(0.0001)\end{array}$ \\
\hline Country FE & Yes & Yes & Yes & Yes & Yes & Yes & Yes & Yes \\
\hline Time FE & No & No & No & No & No & No & No & No \\
\hline Adj. $R^{2}$ & 0.9397 & 0.9280 & 0.9387 & 0.9163 & 0.9077 & 0.8760 & 0.8625 & 0.8443 \\
\hline Obs. & 657 & 638 & 638 & 657 & 189 & 189 & 189 & 189 \\
\hline No. countries & 23 & 23 & 23 & 23 & 23 & 23 & 23 & 23 \\
\hline \multicolumn{9}{|c|}{ Panel B: Europe and Central Asia } \\
\hline \multirow{2}{*}{ Variable } & \multicolumn{4}{|c|}{ Panel Least Squares } & \multicolumn{4}{|c|}{ Panel Fully Modified Least Squares (FMOLS) } \\
\hline & Model 1 & Model 2 & Model 3 & Model 4 & Model 5 & Model 6 & Model 7 & Model 8 \\
\hline Constant & $\begin{array}{c}7.3722 * * * \\
(0.0001)\end{array}$ & $\begin{array}{c}7.6585^{* * *} \\
(0.0001)\end{array}$ & $\begin{array}{c}7.3019^{* * *} \\
(0.0001)\end{array}$ & $\begin{array}{c}7.3110^{* * *} \\
(0.0001)\end{array}$ & & & & \\
\hline$G R K$ & $\begin{array}{c}0.0099 * * * \\
(0.0021)\end{array}$ & $\begin{array}{c}0.0094^{* * *} \\
(0.0031)\end{array}$ & $\begin{array}{c}0.0121^{* * *} \\
(0.0010)\end{array}$ & $\begin{array}{l}0.0068^{* *} \\
(0.0254)\end{array}$ & $\begin{array}{l}0.0115^{* *} \\
(0.0254)\end{array}$ & $\begin{array}{l}0.0097^{* *} \\
(0.0170)\end{array}$ & $\begin{array}{c}0.0118^{* * *} \\
(0.0019)\end{array}$ & $\begin{array}{l}0.0111^{* *} \\
(0.0438)\end{array}$ \\
\hline$G R L$ & $\begin{array}{c}0.1820 * * * \\
(0.0001)\end{array}$ & $\begin{array}{c}0.1187^{* * *} \\
(0.0001)\end{array}$ & $\begin{array}{c}0.1385 * * * \\
(0.0001)\end{array}$ & $\begin{array}{l}0.0757^{* *} \\
(0.0238)\end{array}$ & $\begin{array}{c}0.2233^{* * *} \\
(0.0001)\end{array}$ & $\begin{array}{c}0.1379 * * * \\
(0.0009)\end{array}$ & $\begin{array}{c}0.1560 * * * \\
(0.0001)\end{array}$ & $\begin{array}{c}0.0513^{* * *} \\
(0.0001)\end{array}$ \\
\hline GOV & $\begin{array}{c}0.0101^{* * *} \\
(0.0009)\end{array}$ & $\begin{array}{l}0.0038 \text { * } \\
(0.0898)\end{array}$ & $\begin{array}{c}0.0066^{* * *} \\
(0.0087)\end{array}$ & $\begin{array}{c}0.0098^{* * *} \\
(0.0004)\end{array}$ & $\begin{array}{c}0.0120^{* * *} \\
(0.0044)\end{array}$ & $\begin{array}{c}0.0036 \\
(0.3283)\end{array}$ & $\begin{array}{l}0.0076^{* *} \\
(0.0274)\end{array}$ & $\begin{array}{c}0.0118^{* * *} \\
(0.0001)\end{array}$ \\
\hline OPEN & $\begin{array}{l}0.0013 \text { * } \\
(0.0702)\end{array}$ & $\begin{array}{c}0.0020 \\
(0.7062)\end{array}$ & $\begin{array}{c}0.0016 \\
(0.3347)\end{array}$ & $\begin{array}{c}0.0038^{* * *} \\
(0.0001)\end{array}$ & $\begin{array}{l}0.0030 \text { * } \\
(0.0643)\end{array}$ & $\begin{array}{c}0.0022 * * * \\
(0.0001)\end{array}$ & $\begin{array}{c}0.0010 \\
(0.4151)\end{array}$ & $\begin{array}{c}0.0060^{* * *} \\
(0.0001)\end{array}$ \\
\hline$I N F$ & $\begin{array}{c}-0.0001 * * \\
(0.0280)\end{array}$ & $\begin{array}{c}-0.0001 \\
(0.1114)\end{array}$ & $\begin{array}{c}-0.0002^{* * *} \\
(0.0025)\end{array}$ & $\begin{array}{c}-0.0001 \text { ** } \\
(0.0228)\end{array}$ & $\begin{array}{c}-0.0002^{* * *} \\
(0.0033)\end{array}$ & $\begin{array}{c}-0.0002^{* * *} \\
(0.0073)\end{array}$ & $\begin{array}{c}-0.0002 * * * \\
(0.0001)\end{array}$ & $\begin{array}{c}-0.0001 * * * \\
(0.6330)\end{array}$ \\
\hline$B C D$ & $\begin{array}{c}-0.0260 \\
(0.6489)\end{array}$ & $\begin{array}{c}-0.1143 \text { ** } \\
(0.0225)\end{array}$ & $\begin{array}{c}-0.0473 \\
(0.3167)\end{array}$ & $\begin{array}{c}-0.1194 * \\
(0.0646)\end{array}$ & $\begin{array}{c}-0.0058 \\
(0.9470)\end{array}$ & $\begin{array}{c}-0.1196 \\
(0.1041)\end{array}$ & $\begin{array}{c}-0.0648^{* * *} \\
(0.0001)\end{array}$ & $\begin{array}{c}-0.1059 * * * \\
(0.0001)\end{array}$ \\
\hline$D C P S$ & $\begin{array}{c}0.0105^{* * *} \\
(0.0001)\end{array}$ & & & & $\begin{array}{c}0.0089 * * * \\
(0.0004)\end{array}$ & & & \\
\hline$D C B S$ & & $\begin{array}{c}0.0128^{* * *} \\
(0.0001)\end{array}$ & & & & $\begin{array}{c}0.0130 * * * \\
(0.0001)\end{array}$ & & \\
\hline$L L$ & & & $\begin{array}{c}0.0142^{* * *} \\
(0.0001)\end{array}$ & & & & $\begin{array}{c}0.0148^{* * *} \\
(0.0001)\end{array}$ & \\
\hline GDS & & & & $\begin{array}{c}0.0126^{* * *} \\
(0.0001)\end{array}$ & & & & $\begin{array}{c}0.0162^{* * *} \\
(0.0001)\end{array}$ \\
\hline Country FE & Yes & Yes & Yes & Yes & Yes & Yes & Yes & Yes \\
\hline Time FE & No & No & No & No & No & No & No & No \\
\hline Adj. $R^{2}$ & 0.9102 & 0.9190 & 0.9231 & 0.8761 & 0.8990 & 0.9121 & 0.9097 & 0.9097 \\
\hline Obs. & 471 & 490 & 490 & 559 & 334 & 382 & 382 & 466 \\
\hline No. countries & 44 & 44 & 44 & 44 & 44 & 44 & 44 & 44 \\
\hline
\end{tabular}


Table A3. Cont.

\begin{tabular}{|c|c|c|c|c|c|c|c|c|}
\hline \multicolumn{9}{|c|}{ Panel C: Latin America and the Caribbean } \\
\hline \multirow{2}{*}{ Variable } & \multicolumn{4}{|c|}{ Panel Least Squares } & \multicolumn{4}{|c|}{ Panel Fully Modified Least Squares (FMOLS) } \\
\hline & Model 1 & Model 2 & Model 3 & Model 4 & Model 5 & Model 6 & Model 7 & Model 8 \\
\hline Constant & $\begin{array}{c}7.8774^{* * *} \\
(0.0001)\end{array}$ & $\begin{array}{c}7.7955^{* * *} \\
(0.0001)\end{array}$ & $\begin{array}{c}7.8261 * * * \\
(0.0001)\end{array}$ & $\begin{array}{c}7.9695 * * * \\
(0.0001)\end{array}$ & & & & \\
\hline$G R K$ & $\begin{array}{c}0.0163^{* * *} \\
(0.0002)\end{array}$ & $\begin{array}{c}0.0105^{* * *} \\
(0.0001)\end{array}$ & $\begin{array}{c}0.0110^{* * *} \\
(0.0004)\end{array}$ & $\begin{array}{c}0.0179 * * * \\
(0.0001)\end{array}$ & $\begin{array}{c}0.0285 * * * \\
(0.0001)\end{array}$ & $\begin{array}{c}0.0250 * * * \\
(0.0001)\end{array}$ & $\begin{array}{c}0.0233^{* * *} \\
(0.0008)\end{array}$ & $\begin{array}{c}0.0233^{* * *} \\
(0.0001)\end{array}$ \\
\hline$G R L$ & $\begin{array}{c}0.0467^{* * *} \\
(0.0001)\end{array}$ & $\begin{array}{l}0.0156^{* *} \\
(0.0263)\end{array}$ & $\begin{array}{c}0.0267^{* * *} \\
(0.0003)\end{array}$ & $\begin{array}{c}0.0406^{* * *} \\
(0.0001)\end{array}$ & $\begin{array}{c}0.3132^{* * *} \\
(0.0010)\end{array}$ & $\begin{array}{c}0.2683^{* * *} \\
(0.0009)\end{array}$ & $\begin{array}{c}0.2441^{* * *} \\
(0.0006)\end{array}$ & $\begin{array}{c}0.2961^{* * *} \\
(0.0001)\end{array}$ \\
\hline GOV & $\begin{array}{c}0.0194^{* * *} \\
(0.0001)\end{array}$ & $\begin{array}{c}0.0142 * * * \\
(0.0001)\end{array}$ & $\begin{array}{c}0.0115^{* * *} \\
(0.0009)\end{array}$ & $\begin{array}{c}0.0191 * * * \\
(0.0001)\end{array}$ & $\begin{array}{c}0.0103 * * * \\
(0.0001)\end{array}$ & $\begin{array}{c}0.0113 * * * \\
(0.0001)\end{array}$ & $\begin{array}{c}0.0089 * * * \\
(0.0010)\end{array}$ & $\begin{array}{c}0.0132 * * * \\
(0.0001)\end{array}$ \\
\hline OPEN & $\begin{array}{c}0.0016^{* * *} \\
(0.0013)\end{array}$ & $\begin{array}{c}0.0016^{* * *} \\
(0.0001)\end{array}$ & $\begin{array}{c}0.0017^{* * *} \\
(0.0007)\end{array}$ & $\begin{array}{c}0.0014^{* * *} \\
(0.0009)\end{array}$ & $\begin{array}{c}0.0045 \\
(0.1098)\end{array}$ & $\begin{array}{l}0.0026 \text { * } \\
(0.0572)\end{array}$ & $\begin{array}{c}0.0018^{* * *} \\
(0.0033)\end{array}$ & $\begin{array}{c}0.0012^{* * *} \\
(0.0009)\end{array}$ \\
\hline$I N F$ & $\begin{array}{c}-0.0001 * * * \\
(0.0001)\end{array}$ & $\begin{array}{c}-0.0001 * * \\
(0.0254)\end{array}$ & $\begin{array}{c}-0.0001 * * \\
(0.0328)\end{array}$ & $\begin{array}{c}-0.0001^{* * *} \\
(0.0069)\end{array}$ & $\begin{array}{c}-0.0001^{* *} \\
(0.0159)\end{array}$ & $\begin{array}{c}-0.0001 \text { *** } \\
(0.0002)\end{array}$ & $\begin{array}{c}-0.0001^{* * *} \\
(0.0001)\end{array}$ & $\begin{array}{c}-0.0001 \text { *** } \\
(0.0001)\end{array}$ \\
\hline$B C D$ & $\begin{array}{c}-0.15611^{* * *} \\
(0.0001)\end{array}$ & $\begin{array}{c}-0.1553^{* * *} \\
(0.0001)\end{array}$ & $\begin{array}{c}-0.1256^{* * *} \\
(0.0001)\end{array}$ & $\begin{array}{c}-0.1466 \text { *** } \\
(0.0001)\end{array}$ & $\begin{array}{c}-0.1508 \text { *** } \\
(0.0001)\end{array}$ & $\begin{array}{c}-0.1194^{* * *} \\
(0.0001)\end{array}$ & $\begin{array}{c}-0.1105^{* * *} \\
(0.0008)\end{array}$ & $\begin{array}{c}-0.1221 \text { *** } \\
(0.0002)\end{array}$ \\
\hline$D C P S$ & $\begin{array}{c}0.0019 * * \\
(0.0131)\end{array}$ & & & & $\begin{array}{c}0.0025^{* * *} \\
(0.0001)\end{array}$ & & & \\
\hline$D C B S$ & & $\begin{array}{c}0.0075 * * * \\
(0.0001)\end{array}$ & & & & $\begin{array}{c}0.0017^{* * *} \\
(0.0001)\end{array}$ & & \\
\hline$L L$ & & & $\begin{array}{c}0.0058^{* * *} \\
(0.0001)\end{array}$ & & & & $\begin{array}{c}0.0036^{* * *} \\
(0.0001)\end{array}$ & \\
\hline GDS & & & & $\begin{array}{c}0.0051^{* * *} \\
(0.0016)\end{array}$ & & & & $\begin{array}{c}0.0073^{* * *} \\
(0.0001)\end{array}$ \\
\hline Country FE & Yes & Yes & Yes & Yes & Yes & Yes & Yes & Yes \\
\hline Time FE & No & No & No & No & No & No & No & No \\
\hline Adj. $R^{2}$ & 0.9229 & 0.9391 & 0.9398 & 0.9272 & 0.9173 & 0.9456 & 0.9494 & 0.9467 \\
\hline Obs. & 1241 & 1281 & 1281 & 1281 & 546 & 570 & 570 & 570 \\
\hline No. countries & 33 & 33 & 33 & 33 & 33 & 33 & 33 & 33 \\
\hline \multicolumn{9}{|c|}{ Panel D: Middle East and North Africa } \\
\hline \multirow{2}{*}{ Variable } & \multicolumn{4}{|c|}{ Panel Least Squares } & \multicolumn{4}{|c|}{ Panel Fully Modified Least Squares (FMOLS) } \\
\hline & Model 1 & Model 2 & Model 3 & Model 4 & Model 5 & Model 6 & Model 7 & Model 8 \\
\hline Constant & $\begin{array}{c}8.8233^{* * *} \\
(0.0001)\end{array}$ & $\begin{array}{c}8.9514^{* * *} \\
(0.0001)\end{array}$ & $\begin{array}{c}8.8982 * * * \\
(0.0001)\end{array}$ & $\begin{array}{c}8.8897 * * * \\
(0.0001)\end{array}$ & & & & \\
\hline$G R K$ & $\begin{array}{c}-0.0035 * \\
(0.0682)\end{array}$ & $\begin{array}{c}-0.0037^{*} \\
(0.0511)\end{array}$ & $\begin{array}{c}-0.0035^{*} \\
(0.0749)\end{array}$ & $\begin{array}{c}-0.0036^{* *} \\
(0.0481)\end{array}$ & $\begin{array}{c}-0.0219^{* * *} \\
(0.0001)\end{array}$ & $\begin{array}{c}-0.0212^{* * *} \\
(0.0002)\end{array}$ & $\begin{array}{c}-0.0203^{* * *} \\
(0.0001)\end{array}$ & $\begin{array}{c}-0.0205^{* * *} \\
(0.0004)\end{array}$ \\
\hline$G R L$ & $\begin{array}{c}0.0050 \\
(0.4376)\end{array}$ & $\begin{array}{c}0.0033 \\
(0.5813)\end{array}$ & $\begin{array}{c}0.0035 \\
(0.5504)\end{array}$ & $\begin{array}{c}0.0081 \\
(0.5372)\end{array}$ & $\begin{array}{c}0.0065 \\
(0.5743)\end{array}$ & $\begin{array}{c}0.0018 \\
(0.8777)\end{array}$ & $\begin{array}{c}0.0138 \\
(0.1612)\end{array}$ & $\begin{array}{c}0.0052 \\
(0.6389)\end{array}$ \\
\hline GOV & $\begin{array}{l}0.0077^{* *} \\
(0.0259)\end{array}$ & $\begin{array}{l}0.0068 \text { ** } \\
(0.0432)\end{array}$ & $\begin{array}{l}0.0080 * * \\
(0.0251)\end{array}$ & $\begin{array}{l}0.0070 * * \\
(0.0257)\end{array}$ & $\begin{array}{l}0.0066^{* *} \\
(0.0436)\end{array}$ & $\begin{array}{c}0.0063 \\
(0.6969)\end{array}$ & $\begin{array}{c}0.0045 \\
(0.1110)\end{array}$ & $\begin{array}{c}0.0034 \\
(0.2890)\end{array}$ \\
\hline OPEN & $\begin{array}{l}0.0028 * \\
(0.0677)\end{array}$ & $\begin{array}{l}0.0018 * \\
(0.0785)\end{array}$ & $\begin{array}{c}0.0016 \\
(0.1447)\end{array}$ & $\begin{array}{l}0.0015 * \\
(0.0506)\end{array}$ & $\begin{array}{c}0.0075^{* * *} \\
(0.0001)\end{array}$ & $\begin{array}{c}0.0066^{* * *} \\
(0.0001)\end{array}$ & $\begin{array}{c}0.0060^{* * *} \\
(0.0007)\end{array}$ & $\begin{array}{c}0.0084^{* * *} \\
(0.0005)\end{array}$ \\
\hline$I N F$ & $\begin{array}{l}-0.0030 \\
(0.1216)\end{array}$ & $\begin{array}{l}-0.0032 \\
(0.1080)\end{array}$ & $\begin{array}{c}-0.0034 \\
(0.0754)\end{array}$ & $\begin{array}{c}-0.0035 * \\
(0.0766)\end{array}$ & $\begin{array}{c}-0.0028 * \\
(0.0802)\end{array}$ & $\begin{array}{c}-0.0013 \\
(0.4163)\end{array}$ & $\begin{array}{l}-0.0015 \\
(0.7742)\end{array}$ & $\begin{array}{l}-0.0015 \\
(0.3146)\end{array}$ \\
\hline$B C D$ & $\begin{array}{c}-0.2225^{* * *} \\
(0.0015)\end{array}$ & $\begin{array}{c}-0.2406^{* * *} \\
(0.0012)\end{array}$ & $\begin{array}{c}-0.2312 * * * \\
(0.0012)\end{array}$ & $\begin{array}{c}-0.1313^{* * *} \\
(0.0001)\end{array}$ & $\begin{array}{c}-0.3292 \text { *** } \\
(0.0001)\end{array}$ & $\begin{array}{c}-0.3229^{* * *} \\
(0.0001)\end{array}$ & $\begin{array}{c}-0.3320 * * \\
(0.0001)\end{array}$ & $\begin{array}{c}-0.2791 \text { *** } \\
(0.0002)\end{array}$ \\
\hline$D C P S$ & $\begin{array}{c}0.0018^{* * *} \\
(0.0001)\end{array}$ & & & & $\begin{array}{l}0.0020 * \\
(0.0883)\end{array}$ & & & \\
\hline$D C B S$ & & $\begin{array}{c}0.0050 \\
(0.3069)\end{array}$ & & & & $\begin{array}{c}0.0043^{* * *} \\
(0.0001)\end{array}$ & & \\
\hline$L L$ & & & $\begin{array}{c}0.0010 \\
(0.8913)\end{array}$ & & & & $\begin{array}{c}0.0016^{* * *} \\
(0.0026)\end{array}$ & \\
\hline GDS & & & & $\begin{array}{c}0.0040 \\
(0.7297)\end{array}$ & & & & $\begin{array}{c}-0.0135 * * * \\
(0.0001)\end{array}$ \\
\hline Country FE & Yes & Yes & Yes & Yes & Yes & Yes & Yes & Yes \\
\hline Time FE & No & No & No & No & No & No & No & No \\
\hline Adj. $R^{2}$ & 0.9734 & 0.9735 & 0.9730 & 0.9730 & 0.8056 & 0.8207 & 0.8130 & 0.9190 \\
\hline Obs. & 511 & 502 & 511 & 512 & 180 & 175 & 180 & 2,348 \\
\hline No. countries & 15 & 15 & 15 & 15 & 15 & 15 & 15 & 15 \\
\hline
\end{tabular}


Table A3. Cont.

\begin{tabular}{|c|c|c|c|c|c|c|c|c|}
\hline \multicolumn{9}{|c|}{ Panel E: South Asia } \\
\hline \multirow{2}{*}{ Variable } & \multicolumn{4}{|c|}{ Panel Least Squares } & \multicolumn{4}{|c|}{ Panel Fully Modified Least Squares (FMOLS) } \\
\hline & Model 1 & Model 2 & Model 3 & Model 4 & Model 5 & Model 6 & Model 7 & Model 8 \\
\hline Constant & $\begin{array}{c}6.8732^{* * *} \\
(0.0001)\end{array}$ & $\begin{array}{c}6.9354 * * * \\
(0.0001)\end{array}$ & $\begin{array}{c}6.5700 * * * \\
(0.0001)\end{array}$ & $\begin{array}{c}6.8860 * * * \\
(0.0001)\end{array}$ & & & & \\
\hline$G R K$ & $\begin{array}{c}0.0129^{* * *} \\
(0.0001)\end{array}$ & $\begin{array}{c}0.0106^{* * *} \\
(0.0003)\end{array}$ & $\begin{array}{l}0.0079 * * \\
(0.0197)\end{array}$ & $\begin{array}{c}0.0150 * * * \\
(0.0047)\end{array}$ & $\begin{array}{c}0.0207^{* * *} \\
(0.0003)\end{array}$ & $\begin{array}{c}0.0208^{* * *} \\
(0.0002)\end{array}$ & $\begin{array}{c}0.0118^{* * *} \\
(0.0001)\end{array}$ & $\begin{array}{c}0.0210 * * * \\
(0.0001)\end{array}$ \\
\hline$G R L$ & $\begin{array}{c}0.0133^{* * *} \\
(0.0003)\end{array}$ & $\begin{array}{c}0.1095^{* * *} \\
(0.0019)\end{array}$ & $\begin{array}{l}0.0749 * \\
(0.0141)\end{array}$ & $\begin{array}{c}0.2157^{* * *} \\
(0.0004)\end{array}$ & $\begin{array}{c}0.1116^{* * *} \\
(0.0001)\end{array}$ & $\begin{array}{c}0.1123^{* * *} \\
(0.0009)\end{array}$ & $\begin{array}{c}0.0459 * * \\
(0.0131)\end{array}$ & $\begin{array}{c}0.2822 \text { *** } \\
(0.0001)\end{array}$ \\
\hline GOV & $\begin{array}{c}-0.0396^{* * *} \\
(0.0002)\end{array}$ & $\begin{array}{c}-0.0435^{* * *} \\
(0.0001)\end{array}$ & $\begin{array}{c}-0.0426^{* * *} \\
(0.0005)\end{array}$ & $\begin{array}{c}-0.0444^{* * *} \\
(0.0001)\end{array}$ & $\begin{array}{c}-0.0854^{* * *} \\
(0.0001)\end{array}$ & $\begin{array}{c}-0.0854^{* * *} \\
(0.0001)\end{array}$ & $\begin{array}{c}-0.0892 * * * \\
(0.0004)\end{array}$ & $\begin{array}{c}-0.0783 \text { *** } \\
(0.0001)\end{array}$ \\
\hline OPEN & $\begin{array}{c}0.0069 * * * \\
(0.0001)\end{array}$ & $\begin{array}{c}0.0069 * * * \\
(0.0001)\end{array}$ & $\begin{array}{c}0.0070 * * * \\
(0.0001)\end{array}$ & $\begin{array}{c}0.0100 * * * \\
(0.0001)\end{array}$ & $\begin{array}{c}0.0077^{* * *} \\
(0.0001)\end{array}$ & $\begin{array}{c}0.0075^{* * *} \\
(0.0001)\end{array}$ & $\begin{array}{c}0.0074^{* * *} \\
(0.0007)\end{array}$ & $\begin{array}{c}0.0041^{* * *} \\
(0.0001)\end{array}$ \\
\hline$I N F$ & $\begin{array}{c}-0.0150 \\
(0.0134)\end{array}$ & $\begin{array}{c}-0.0143^{* *} \\
(0.0169)\end{array}$ & $\begin{array}{l}-0.0085 \\
(0.1766)\end{array}$ & $\begin{array}{c}-0.0150 * * \\
(0.0512)\end{array}$ & $\begin{array}{c}-0.0106^{* * *} \\
(0.0001)\end{array}$ & $\begin{array}{c}-0.0106^{* * *} \\
(0.0002)\end{array}$ & $\begin{array}{c}-0.0075^{* * *} \\
(0.0009)\end{array}$ & $\begin{array}{c}-0.0107^{* * *} \\
(0.0001)\end{array}$ \\
\hline$B C D$ & $\begin{array}{c}-0.0452 \\
(0.3997)\end{array}$ & $\begin{array}{l}-0.0417 \\
(0.4337)\end{array}$ & $\begin{array}{l}-0.0183 \\
(0.7643)\end{array}$ & $\begin{array}{c}-0.0182 \text { *** } \\
(0.0007)\end{array}$ & $\begin{array}{c}-0.1140^{* * *} \\
(0.0043)\end{array}$ & $\begin{array}{c}-0.1134^{* * *} \\
(0.0001)\end{array}$ & $\begin{array}{c}-0.0712 * * \\
(0.0210)\end{array}$ & $\begin{array}{l}-0.0325 \\
(0.5084)\end{array}$ \\
\hline$D C P S$ & $\begin{array}{c}0.0130 * * * \\
(0.0001)\end{array}$ & & & & $\begin{array}{c}0.0111^{* * *} \\
(0.0001)\end{array}$ & & & \\
\hline$D C B S$ & & $\begin{array}{c}0.0138^{* * *} \\
(0.0001)\end{array}$ & & & & $\begin{array}{c}0.0111^{* * *} \\
(0.0001)\end{array}$ & & \\
\hline$L L$ & & & $\begin{array}{c}0.0148^{* * *} \\
(0.0001)\end{array}$ & & & & $\begin{array}{c}0.0132 * * * \\
(0.0001)\end{array}$ & \\
\hline GDS & & & & $\begin{array}{c}0.0059 * * * \\
(0.0001)\end{array}$ & & & & $\begin{array}{c}0.0157^{* * *} \\
(0.0001)\end{array}$ \\
\hline Country FE & Yes & Yes & Yes & Yes & Yes & Yes & Yes & Yes \\
\hline Time FE & No & No & No & No & No & No & No & No \\
\hline $\operatorname{Adj} . R^{2}$ & 0.9395 & 0.9425 & 0.9449 & 0.9239 & 0.9304 & 0.9305 & 0.9343 & 0.9252 \\
\hline Obs. & 258 & 255 & 258 & 258 & 152 & 152 & 152 & 152 \\
\hline No. countries & 7 & 7 & 7 & 7 & 7 & 7 & 7 & 7 \\
\hline \multicolumn{9}{|c|}{ Panel F: Sub-Saharan Africa } \\
\hline \multirow{2}{*}{ Variable } & \multicolumn{4}{|c|}{ Panel Least Squares } & \multicolumn{4}{|c|}{ Panel Fully Modified Least Squares (FMOLS) } \\
\hline & Model 1 & Model 2 & Model 3 & Model 4 & Model 5 & Model 6 & Model 7 & Model 8 \\
\hline Constant & $\begin{array}{c}6.4326^{* * *} \\
(0.0001)\end{array}$ & $\begin{array}{c}6.3349 * * * \\
(0.0001)\end{array}$ & $\begin{array}{c}6.3235^{* * *} \\
(0.0001)\end{array}$ & $\begin{array}{c}6.4340 * * * \\
(0.0001)\end{array}$ & & & & \\
\hline$G R K$ & $\begin{array}{c}0.0121 * * * \\
(0.0001)\end{array}$ & $\begin{array}{c}0.0116^{* * *} \\
(0.0003)\end{array}$ & $\begin{array}{c}0.0114^{* * *} \\
(0.0002)\end{array}$ & $\begin{array}{c}0.0102 * * * \\
(0.0001)\end{array}$ & $\begin{array}{c}0.0225^{* * *} \\
(0.0001)\end{array}$ & $\begin{array}{c}0.0225^{* * *} \\
(0.0002)\end{array}$ & $\begin{array}{c}0.0100 * * * \\
(0.0001)\end{array}$ & $\begin{array}{c}0.0184^{* * *} \\
(0.0001)\end{array}$ \\
\hline$G R L$ & $\begin{array}{c}0.0241 \\
(0.1861)\end{array}$ & $\begin{array}{c}0.0020 \\
(0.8634)\end{array}$ & $\begin{array}{c}0.0117 \\
(0.3735)\end{array}$ & $\begin{array}{l}0.0410 * * \\
(0.0367)\end{array}$ & $\begin{array}{l}0.0205 * \\
(0.0674)\end{array}$ & $\begin{array}{l}0.0205 * \\
(0.0674)\end{array}$ & $\begin{array}{l}0.0202 * * \\
(0.0221)\end{array}$ & $\begin{array}{c}0.0472 * * * \\
(0.0001)\end{array}$ \\
\hline GOV & $\begin{array}{c}0.0078^{* * *} \\
(0.0039)\end{array}$ & $\begin{array}{c}0.0073 * * * \\
(0.0062)\end{array}$ & $\begin{array}{l}0.0074^{* *} \\
(0.0138)\end{array}$ & $\begin{array}{c}0.0094^{* * *} \\
(0.0009)\end{array}$ & $\begin{array}{c}0.0313^{* * *} \\
(0.0001)\end{array}$ & $\begin{array}{c}0.0313^{* * *} \\
(0.0001)\end{array}$ & $\begin{array}{c}0.0170 * * * \\
(0.0003)\end{array}$ & $\begin{array}{c}0.0272 * * * \\
(0.0001)\end{array}$ \\
\hline OPEN & $\begin{array}{c}0.0017^{* * *} \\
(0.0001)\end{array}$ & $\begin{array}{c}0.0015^{* * *} \\
(0.0001)\end{array}$ & $\begin{array}{c}0.0014^{* * *} \\
(0.0001)\end{array}$ & $\begin{array}{c}0.0029 * * * \\
(0.0001)\end{array}$ & $\begin{array}{c}0.0034^{* * *} \\
(0.0001)\end{array}$ & $\begin{array}{c}0.0034^{* * *} \\
(0.0001)\end{array}$ & $\begin{array}{c}0.0010^{* * *} \\
(0.0020)\end{array}$ & $\begin{array}{c}0.0033^{* * *} \\
(0.0001)\end{array}$ \\
\hline$I N F$ & $\begin{array}{l}-0.0001 \\
(0.5129)\end{array}$ & $\begin{array}{c}-0.0001 \\
(0.9877)\end{array}$ & $\begin{array}{l}-0.0001 \\
(0.5878)\end{array}$ & $\begin{array}{l}-0.0001 \\
(0.8180)\end{array}$ & $\begin{array}{c}-0.0031 * * * \\
(0.0001)\end{array}$ & $\begin{array}{c}-0.0031 * * * \\
(0.0002)\end{array}$ & $\begin{array}{c}-0.0031 * * * \\
(0.0009)\end{array}$ & $\begin{array}{c}-0.0029 * * * \\
(0.0001)\end{array}$ \\
\hline$B C D$ & $\begin{array}{c}-0.0467 * \\
(0.0995)\end{array}$ & $\begin{array}{c}-0.0314^{* * *} \\
(0.0001)\end{array}$ & $\begin{array}{c}-0.0260^{* * *} \\
(0.0001)\end{array}$ & $\begin{array}{l}-0.0493 \\
(0.1231)\end{array}$ & $\begin{array}{l}-0.0093 \\
(0.6404)\end{array}$ & $\begin{array}{l}-0.0093 \\
(0.6404)\end{array}$ & $\begin{array}{c}-0.0416^{* * *} \\
(0.0021)\end{array}$ & $\begin{array}{l}-0.0077 \\
(0.7514)\end{array}$ \\
\hline$D C P S$ & $\begin{array}{c}0.0063^{* * *} \\
(0.0001)\end{array}$ & & & & $\begin{array}{l}-0.0013 \\
(0.1042)\end{array}$ & & & \\
\hline$D C B S$ & & $\begin{array}{c}0.0117^{* * *} \\
(0.0001)\end{array}$ & & & & $\begin{array}{l}-0.0013 \\
(0.1042)\end{array}$ & & \\
\hline$L L$ & & & $\begin{array}{c}0.0085^{* * *} \\
(0.0001)\end{array}$ & & & & $\begin{array}{c}0.0133^{* * *} \\
(0.0001)\end{array}$ & \\
\hline GDS & & & & $\begin{array}{c}0.0058^{* * *} \\
(0.0001)\end{array}$ & & & & $\begin{array}{c}0.0111^{* * *} \\
(0.0001)\end{array}$ \\
\hline Country FE & Yes & Yes & Yes & Yes & Yes & Yes & Yes & Yes \\
\hline Time FE & No & No & No & No & No & No & No & No \\
\hline Adj. $R^{2}$ & 0.9070 & 0.9200 & 0.9182 & 0.9065 & 0.7860 & 0.7862 & 0.9257 & 0.9257 \\
\hline Obs. & 1593 & 1530 & 1528 & 1593 & 772 & 772 & 720 & 790 \\
\hline No. countries & 41 & 41 & 41 & 41 & 41 & 41 & 41 & 41 \\
\hline
\end{tabular}

Note: This table shows the regression results for economic growth determinants for six geographic regional groups. The heteroskedasticrobust adjusted standard errors are in parentheses. The signs $* * * * *$, and * indicate statistical significance of $\mathrm{F}$-statistic at $1 \%, 5 \%$, and $10 \%$ levels, respectively. Each equation is estimated using Panel Least Squares and Panel Fully Modified Least Squares estimation methods. 
Table A4. List of countries by geographic region.

\begin{tabular}{|c|c|c|c|}
\hline \multicolumn{4}{|c|}{ Panel A: East Asia and the Pacific $(\mathrm{N}=18)$} \\
\hline Brunei Darussalam & Lao PDR & Philippines & Tonga \\
\hline Cambodia & Malaysia & Samoa & Vanuatu \\
\hline China & Mongolia & Solomon Islands & Vietnam \\
\hline Fiji & Myanmar & Thailand & \\
\hline Indonesia & Papua New Guinea & Timor-Leste & \\
\hline \multicolumn{4}{|c|}{ Panel B: Europe and Central Asia $(\mathrm{N}=20)$} \\
\hline Albania & Bulgaria & Kyrgyz Republic & Serbia \\
\hline Armenia & Croatia & Moldova & Tajikistan \\
\hline Azerbaijan & Georgia & Poland & Turkey \\
\hline Belarus & Hungary & Romania & Turkmenistan \\
\hline Bosnia and Herzegovina & Kazakhstan & Russian Federation & Ukraine \\
\hline \multicolumn{4}{|c|}{ Panel C: Latin America and the Caribbean $(\mathrm{N}=33)$} \\
\hline Antigua and Barbuda & Colombia & Haiti & St. Lucia \\
\hline Argentina & Costa Rica & Honduras & St. Vincent and the Grenadines \\
\hline Aruba & Dominica & Jamaica & Suriname \\
\hline Bahamas, The & Dominican Republic & Mexico & Trinidad and Tobago \\
\hline Barbados & Ecuador & Nicaragua & Uruguay \\
\hline Belize & El Salvador & Panama & Venezuela, RB \\
\hline Bolivia & Grenada & Paraguay & \\
\hline Brazil & Guatemala & Peru & \\
\hline Chile & Guyana & St. Kitts and Nevis & \\
\hline \multicolumn{4}{|c|}{ Panel D: Middle East and North Africa $(\mathrm{N}=17)$} \\
\hline Algeria & Jordan & Oman & United Arab Emirates \\
\hline Bahrain & Kuwait & Qatar & Yemen, Rep. \\
\hline Djibouti & Lebanon & Saudi Arabia & \\
\hline Egypt, Arab Rep. & Libya & Syrian Arab Republic & \\
\hline Iran, Islamic Rep. & Morocco & Tunisia & \\
\hline \multicolumn{4}{|l|}{ Panel E: South Asia $(\mathrm{N}=7)$} \\
\hline Bangladesh & India & Nepal & Sri Lanka \\
\hline Bhutan & Maldives & Pakistan & \\
\hline \multicolumn{4}{|c|}{ Panel F: Sub-Saharan Africa $(N=43)$} \\
\hline Angola & Congo, Rep. & Lesotho & Rwanda \\
\hline Benin & Cote d'Ivoire & Liberia & Senegal \\
\hline Botswana & Equatorial Guinea & Madagascar & Seychelles \\
\hline Burkina Faso & Eritrea & Malawi & Sierra Leone \\
\hline Burundi & Ethiopia & Mali & South Africa \\
\hline Cameroon & Gabon & Mauritania & Sudan \\
\hline Cape Verde & Gambia, The & Mauritius & Tanzania \\
\hline Central African Republic & Ghana & Mozambique & Togo \\
\hline Chad & Guinea & Namibia & Uganda \\
\hline Comoros & Guinea-Bissau & Niger & Zambia \\
\hline Congo, Dem. Rep. & Kenya & Nigeria & \\
\hline
\end{tabular}

\section{References}

Adu, George, George Marbuah, and Justice Tei Mensah. 2013. Financial development and economic growth in Ghana: Does the measure of financial development matter? Review of Development Finance 3: 192-203. [CrossRef]

Adusei, Michael. 2013. Does Finance Promote Growth in Botswana? Research in Applied Economics 5: 70-81. [CrossRef]

Agbetsiafa, Douglas. 2004. The finance-growth nexus: Evidence from Sub-Saharan Africa. Savings and Development 28: 271-88. [CrossRef]

Aghion, Philippe, Ufuk Akcigit, and Peter Howitt. 2014. What do we learn from Schumpeterian growth theory? Handbook of Economic Growth 2: 515-63.

Bekaert, Geert, Campbell R. Harvey, and Christian Lundblad. 2005. Does financial liberalization spur growth? Journal of Financial Economics 77: 3-55. [CrossRef] 
Breitung, Jörg. 2000. The Local Power of Some Unit Root Tests for Panel Data. In Advances in Econometrics. Edited by B. Baltagi. Volume 15: Nonstationary Panels, Panel Cointegration, and Dynamic Panels. Amsterdam: JAI Press, pp. 161-78.

Botev, Jaroslava, Balázs Égert, and Fredj Jawadi. 2019. The nonlinear relationship between economic growth and financial development: Evidence from developing, emerging and advanced economies. International Economics 160: 3-13. [CrossRef]

Choi, I. 2001. Unit Root Tests for Panel Data. Journal of International Money and Finance 20: 249-72. [CrossRef]

Destek, Mehmet Akif, Avik Sinha, and Samuel Asumadu Sarkodie. 2020. The relationship between financial development and income inequality in Turkey. Economic Structures 9: 11. [CrossRef]

Ehigiamusoe, Kizito Uyi. 2021. The nexus between tourism, financial development, and economic growth: Evidence from African countries. African Development Review 11: 382-96. [CrossRef]

Guru, Biplab Kumar, and Inder Sekhar Yadav. 2019. Financial development and economic growth: Panel evidence from BRICS. Journal of Economics, Finance and Administrative Science 24: 113-26. [CrossRef]

Hadri, Kaddour. 2000. Testing for Stationarity in Heterogeneous Panel Data. Econometric Journal 3: 148-61. [CrossRef]

Hassan, M. Kabir, Benito Sanchez, and Jung-Suk Yu. 2011. Financial development and economic growth: New evidence from panel data. The Quarterly Review of Economics and Finance 51: 88-104. [CrossRef]

Hsueh, Shun-Jen, Yu-Hau Hu, and Chien-Heng Tu. 2013. Economic growth and financial development in Asian countries: A bootstrap panel Granger causality analysis. Economic Modelling 32: 294-301. [CrossRef]

Ibrahim, Muazu, and Paul Alagidede. 2018. Effect of financial development on economic growth in Sub-Saharan Africa. Journal of Policy Modeling 40: 1104-25. [CrossRef]

Im, K. S., M. H. Pesaran, and Y. Shin. 2003. Testing for Unit Roots in Heterogeneous Panels. Journal of Econometrics 115: 53-74. [CrossRef]

Kemal, Abdul Razzaq, Abdul Qayyum, and Muhammad N. Hanif. 2007. Financial development and economic growth: Evidence from a heterogeneous panel of high-income countries. The Lahore Journal of Economics 12: 1-34. [CrossRef]

Kuznets, Simon. 1955. Economic Growth and Income Inequality. The American Economic Review 45: 1-28. Available online: http: //www.jstor.org/stable/1811581 (accessed on 3 August 2021).

Law, Siong Hook, Hui Boon Tan, and W. N. W. Azman-Saini. 2014. Financial Development and Income Inequality at Different Levels of Institutional Quality. Emerging Markets Finance and Trade 50: 21-33. [CrossRef]

Lee, Chien-Chiang, and Chun-Ping Chang. 2009. FDI, financial development, and economic growth: International evidence. Journal of Applied Economics 12: 249-71. [CrossRef]

Levin, A., C. F. Lin, and C. Chu. 2002. Unit Root Tests in Panel Data: Asymptotic and Finite-Sample Properties. Journal of Econometrics 108: 1-24. [CrossRef]

Lewis, W. Arthur. 1956. Theory of Economic Growth. London: Routledge.

Maddala, G. S., and S. Wu. 1999. A Comparative Study of Unit Root Tests with Panel Data and A New Simple Test. Oxford Bulletin of Economics and Statistics 61: 631-52. [CrossRef]

Omri, Anis, Saida Daly, Christophe Rault, and Anissa Chaibi. 2015. Financial development, environmental quality, trade and economic growth: What causes what in MENA countries. Energy Economics 48: 242-52. [CrossRef]

Osei, Michael J., and Jaebeom Kim. 2020. Foreign direct investment and economic growth: Is more financial development better? Economic Modelling 93: 154-61. [CrossRef]

Patrick, Hugh T. 1966. Financial development and economic growth in underdeveloped countries. Economic Development and Cultural Change 14: 174-89. [CrossRef]

Pradhan, Rudra Prakash. 2009. Education and economic growth in India: Using error correction modelling. International Research Journal of Finance and Economics 25: 139-47.

Robinson, Joan. 1952. The Generalization of the General Theory. The Rate of Interest and Other Essays. London: Macmillan.

Rostow, Walt Whitman. 1959. The Stages of Economic Growth. The Economic History Review 12: 1-16. [CrossRef]

Rousseau, Peter L., and Paul Wachtel. 2005. Economic growth and financial depth: Is the relationship extinct already? In WIDER Discussion Paper, No. 2005/10. Helsinki: The United Nations University World Institute for Development Economics Research (UNU-WIDER), ISBN 9291907499.

Rousseau, Peter L., and Paul Wachtel. 2011. What is happening to the impact of financial deepening on economic growth? Economic Inquiry 49: 276-88. [CrossRef]

Schumpeter, Joseph. 1911. The Theory of Economic Development: An Inquiry into Profits, Capital, Interest, and the Business Cycle. Cambridge: Harvard University Press.

Shahbaz, Muhammad, Thi Hong Van Hoang, Mantu Kumar Mahalik, and David Roubaud. 2017. Energy consumption, financial development and economic growth in India: New evidence from a nonlinear and asymmetric analysis. Energy Economics 63: 199-212. [CrossRef]

Song, Chang-Qing, Chun-Ping Chang, and Qiang Gong. 2021. Economic growth, corruption, and financial development: Global evidence. Economic Modelling 94: 822-30. [CrossRef] 
Tiwari, Aviral Kumar, Muhammad Shahbaz, and Faridul Islam. 2013. Does financial development increase rural-urban income inequality? Cointegration analysis in the case of Indian economy. International Journal of Social Economics 40: 151-68. [CrossRef] Yakubu, Zakaria, Nanthakumar Loganathan, Narayan Sethi, and Asan Ali Golam Hassan. 2021. Do Financial Development, Trade Openness and Political Stability Complement for Egypt's Economic Growth? International Journal of International Commerce, Economics and Policy 12: 1-26. 